\title{
12. ANALYSIS OF WET-BULK DENSITY AND SEDIMENT COLOR CYCLES IN PLIOCENE-PLEISTOCENE SEDIMENTS OF THE OWEN RIDGE (SITE 722) AND OMAN MARGIN (SITE 728) ${ }^{1}$
}

\author{
William H. Busch ${ }^{2}$
}

\begin{abstract}
Pliocene and Pleistocene sediments of the Oman margin and Owen Ridge are characterized by continuous alternation of light and dark layers of nannofossil ooze and marly nannofossil ooze and cyclic variation of wet-bulk density. Origin of the wet-bulk density and color cycles was examined at Ocean Drilling Program Site 722 on the Owen Ridge and Site 728 on the Oman margin using 3.4-m.y.-long GRAPE (gamma ray attenuation) wet-bulk density records and records of sediment color represented as changes in gray level on black-and-white core photographs. At Sites 722 and 728 sediments display a weak correlation of decreasing wet-bulk density with increasing darkness of sediment color. Wet-bulk density is inversely related to organic carbon concentration and displays little relation to calcium carbonate concentration, which varies inversely with the abundance of terrigenous sediment components. Sediment color darkens with increasing terrigenous sediment abundance (decreasing carbonate content) and with increasing organic carbon concentration. Upper Pleistocene sediments at Site 722 display a regular pattern of dark colored intervals coinciding with glacial periods, whereas at Site 728 the pattern of color variation is more irregular. There is not a consistent relationship between the dark intervals and their relative wet-bulk density in the upper Pleistocene sections at Sites 722 and 728 , suggesting that dominance of organic matter or terrigenous sediment as primary coloring agents varies. Spectra of wet-bulk density and optical density time series display concentration of variance at orbital periodicities of $100,41,23$, and 19 k.y. A strong 41-k.y. periodicity characterizes wet-bulk density and optical density variation at both sites throughout most of the past $3.4 \mathrm{~m} . \mathrm{y}$. Cyclicity at the 41-k.y. periodicity is characterized by a lack of coherence between wet-bulk density and optical density suggesting that the bulk density and color cycles reflect the mixed influence of varying abundance of terrigenous sediments and organic matter. The 23-k.y. periodicity in wet-bulk density and sediment color cycles is generally characterized by significant coherence between wet-bulk density and optical density, which reflects an inverse relationship between these parameters. Varying organic matter abundance, associated with changes in productivity or preservation, is inferred to more strongly influence changes in wet-bulk density and sediment color at this periodicity.
\end{abstract}

\section{INTRODUCTION}

A major characteristic of most Pliocene and Pleistocene sediments drilled during Ocean Drilling Program Leg 117 is strong cyclicity exhibited by changes in sediment color, wet-bulk density, magnetic susceptibility, and carbonate content. The cyclicity is thought to reflect changes in oceanic productivity/preservation and changes in input of eolian materials (Prell, Niitsuma, et al., 1989). These changes are believed to be strongly associated with the Indian Ocean monsoon through changes in intensity of monsoon-induced coastal upwelling along the Oman margin and associated changes in productivity and structure and intensity of the oxygen minimum zone (OMZ) and changes in the strength of monsoon wind which affects the amount, size, and composition of eolian sediments.

The objective of this paper is to examine the variation of wet-bulk density and sediment color in upper Pliocene and Pleistocene sediments of the Owen Ridge (Site 722) and Oman margin (Site 728), in terms of both the origin of the cyclicity and the periodicity of the cycles. The implication that color cycles in Owen Ridge sediments are a response to climate forcing was suggested by calculation of the Walsh spectrum of color change, in which color was classified as dark, medium, and light. Results of this analysis indicated the dominant periodicities of the cycles matched those of the Milankovitch mechanism

\footnotetext{
${ }^{1}$ Prell, W. L., Niitsuma, N., et al., 1991. Proc. ODP, Sci. Results, 117: College Station, TX (Ocean Drilling Program).

2 Department of Geology and Geophysics, University of New Orleans, New Orleans, LA 70148, U.S.A.
}

for variation of the earth's orbital parameters (Prell, Niitsuma, et al., 1989). Power spectra of magnetic susceptibility time series for Owen Ridge sediments also reveal dominant periodicities that match those of the earth's orbital parameters (deMenocal, 1989). Changes in wet-bulk density of Owen Ridge and Oman margin sediments were observed, during the initial processing of sediment cores, to roughly correspond to changes in sediment color and magnetic susceptibility, suggesting that bulk density variation is also a record of changes in sedimentation associated with climatic change.

\section{DESCRIPTIONS OF STUDY SECTIONS}

\section{Site 722}

Site 722 is located near the crest of the Owen Ridge at a water depth of $2028 \mathrm{~m}$ (Fig. 1). Following uplift of the ridge during late Oligocene to early Miocene time, the site has been above the reach of turbidite deposition associated with the Indus Fan and has accumulated primarily pelagic, carbonate-rich sediments. Site 722 is located at a water depth shallower than the Holocene lysocline at 3900-4000 m (Kolla et al., 1976) and the foraminiferal lysocline at approximately $3300 \mathrm{~m}$ (Cullen and Prell, 1984), and late Neogene sediments are characterized by good carbonate preservation.

The section examined at Site 722 extends from 0 to $108 \mathrm{mbsf}$ and is late Pliocene to Holocene in age. This section is contained within lithologic Unit I (0-221.5 mbsf) at Site 722 (Prell, Niitsuma, et al., 1989) and consists of alternating light and dark beds of foraminifer-bearing nannofossil ooze, nannofossil ooze, and marly nannofossil ooze. Light beds vary in color from gray to light olive gray, light gray, and light greenish gray. Dark beds 


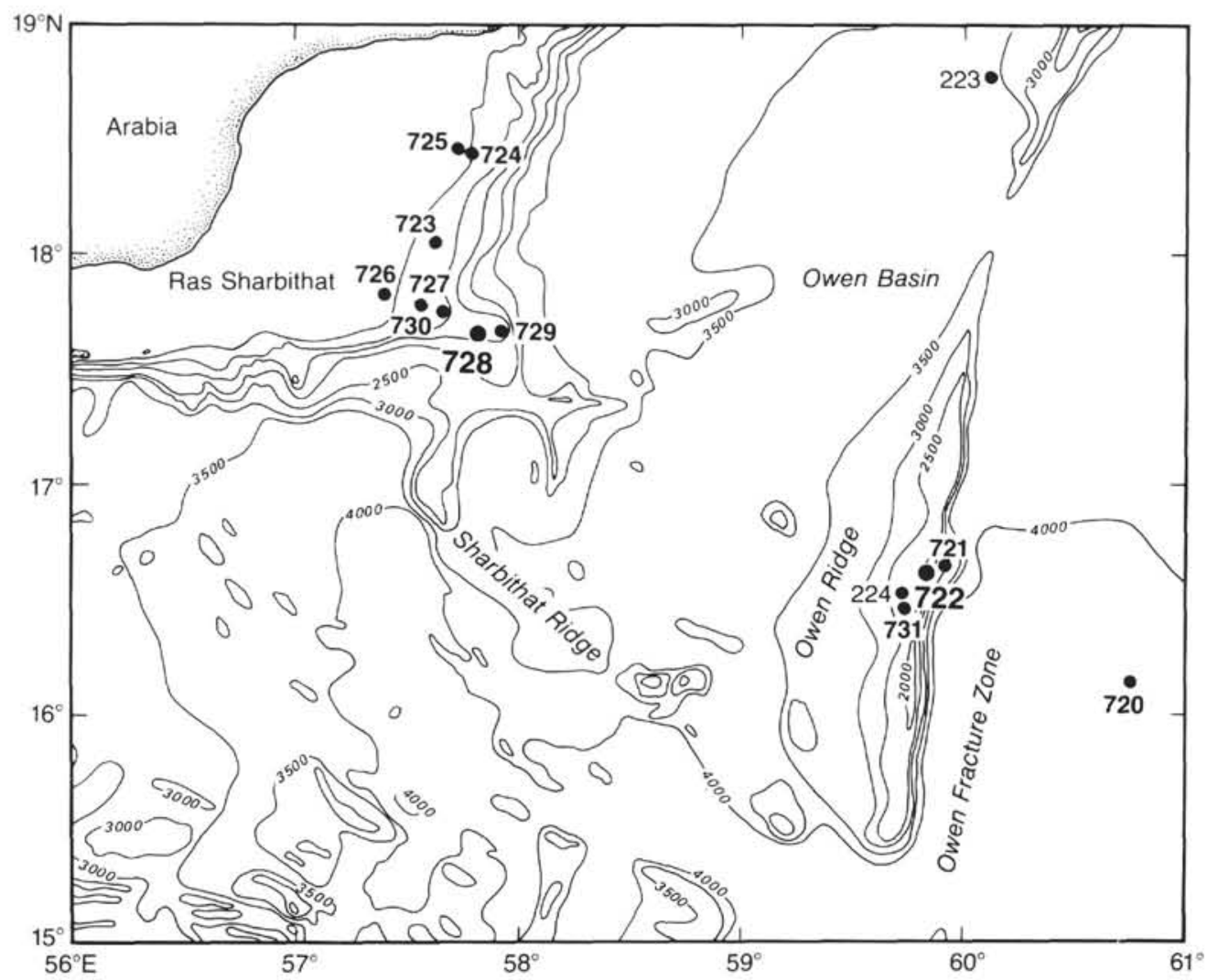

Figure 1. Leg 117 site location map.

range from pale olive to olive gray, olive, and dark olive gray. Smear-slide descriptions (Prell, Niitsuma, et al., 1989) indicate that dark beds contain 10\%-20\% more silty clay than do light beds. Clays and inorganic calcite are the major terrigenous components in Unit I. Clay concentration ranges from $10 \%$ to $30 \%$ with the highest concentrations occurring in dark beds (marly nannofossil oozes) between 45 and 100 mbsf. Calcium carbonate content ranges from $50 \%$ to $79 \%$ for the upper Pliocene to Holocene section with higher calcium carbonate values corresponding to lighter color beds. Organic carbon concentration ranges from $0.4 \%$ to $2.1 \%$ and is generally higher in the darker layers. Biogenic silica concentration is estimated to vary between $0 \%$ and $5 \%$ for the upper Pliocene to Holocene section (D. Murray, pers. comm., 1990).

Lithologic Unit I at Site 722 displays a general trend of increasing wet-bulk density with increasing burial depth. Wetbulk density ranges from $1.65 \mathrm{~g} / \mathrm{cm}^{3}$ near the seafloor to 1.74 $\mathrm{g} / \mathrm{cm}^{3}$ at the base of the unit $(221.5 \mathrm{mbsf})$. A broad wet-bulk density minimum is present from 80 to $110 \mathrm{mbsf}$ and corresponds to an increase in clay abundance and organic carbon concentration. Grain density for most of Unit $\mathrm{I}$ is in the range of 2.55-2.75 g/ $\mathrm{cm}^{3}$ (Prell, Niitsuma, et al., 1989). Low values of grain density are associated with the bulk-density minimum between 80 and $110 \mathrm{mbsf}$, with the lowest values $\left(<2.50 \mathrm{~g} / \mathrm{cm}^{3}\right)$ occurring in the interval from 80 to 90 mbsf.

\section{Site 728}

Site 728 is located on the Oman continental margin at a water depth of $1428 \mathrm{~m}$ (Fig. 1), near the center of a distal slope basin formed by a narrow half-graben in presumed ophiolitic basement. Benthic foraminifers indicate that the site has experienced rapid vertical movement from upper bathyal depths in the late Miocene, rising to neritic depths $(<150 \mathrm{~m})$ in the early Pliocene, and subsiding to upper middle bathyal depths $(>500 \mathrm{~m})$ in the late Pliocene to Pleistocene (Prell, Niitsuma, et al., 1989). Site 728 is located near the lower boundary of the OMZ, which presently extends from 200 to $1200 \mathrm{~m}$ water depth and is characterized by $\mathrm{O}_{2}$ concentrations $<0.2 \mathrm{~mL} / \mathrm{L}$. A zone of high organic carbon concentrations that is present between 80 and 110 mbsf at Site 728 is thought to reflect movement of the site through the OMZ in the late Pliocene. The sedimentary section at Site 728 is more pelagic than other Leg 117 Oman margin sites located at shallower depths, the proportion of biogenic to terrigenous sediment is higher, but it still reflects the proximal effects of monsoonal upwelling.

The section examined at Site 728 extends from 0 to 106 mbsf. It is late-early Pliocene to Holocene in age and is contained within lithologic Subunits IA (0-58 mbsf) and IB (58-320 mbsf) at Site 728 (Prell, Niitsuma, et al., 1989). Subunit IA consists of marly foraminifer nannofossil ooze and foraminifer-bearing, marly nannofossil ooze. Dark and light layers are olive and light olive gray, respectively. Smear-slide observations indicate that the terrigenous sediment component is dominated by clay $(10 \%-$ $35 \%)$ and clay- and silt-sized detrital calcite $(10 \%-40 \%)$. Calcium carbonate content varies between $50 \%$ and $65 \%$, and organic carbon concentration ranges from $0.7 \%$ to $2.4 \%$. Abundant foraminifers ( $>10 \%$ in smear slides) are present in the upper $20 \mathrm{~m}$ of Subunit IA. Subunit IB primarily consists of foraminifer-bearing, marly nannofossil ooze with alternating dark and light beds. Dark intervals are olive, olive gray, and dark olive. Light layers are olive gray and olive. In the interval from the top of Subunit IB (58 mbsf) to $106 \mathrm{mbsf}$, clay abundance ranges from $10 \%$ to $40 \%$, and the amount of inorganic calcite ranges from $5 \%$ to $45 \%$. In this section calcium carbonate content ranges from $34 \%$ to $67 \%$, and organic carbon concentration ranges from $2.0 \%$ to $5.3 \%$. Quantitative determinations of biogenic silica concentration are not available for Site 728. Semiquantitative estimates indicate that radiolarians are absent above 
47 mbsf, present in low concentration of fragments between 47 and 76 mbsf, and common and well preserved below $85 \mathrm{mbsf}$.

Physical properties of sediments in the upper $106 \mathrm{~m}$ at Site 728 vary in response to changes in abundance of foraminifers, siliceous microfossils, and organic matter. Wet-bulk density is highly variable in this interval resulting from changes in both porosity and grain density. In Subunit IA wet-bulk density increases from $1.70 \mathrm{~g} / \mathrm{cm}^{3}$ near the seafloor to $1.75 \mathrm{~g} / \mathrm{cm}^{3}$ at the base of the unit. Within this interval a maximum in wet-bulk density of $1.85 \mathrm{~g} / \mathrm{cm}^{3}$ is present at approximately $30 \mathrm{mbsf}$. Grain density in Subunit IA varies from 2.40 to $2.75 \mathrm{~g} / \mathrm{cm}^{3}$ (Prell, Niitsuma, et al., 1989) and displays high values near 30 mbsf and decreases downsection as organic carbon content increases. In Subunit IB wet-bulk density decreases from 1.75 to $1.66 \mathrm{~g} / \mathrm{cm}^{3}$ in the interval from 58 to 106 mbsf. A wet-bulk density minimum of $1.60 \mathrm{~g} / \mathrm{cm}^{3}$ at approximately $90 \mathrm{mbsf}$ is associated with high concentrations of organic carbon and presence of siliceous microfossils. Grain density in the upper part of Subunit IB is lower than that in Subunit IA, ranging from 2.40 to $2.65 \mathrm{~g} / \mathrm{cm}^{3}$. The lowest grain density measured, $2.40 \mathrm{~g} / \mathrm{cm}^{3}$, coincides with the wet-bulk density minimum at $90 \mathrm{mbsf}$.

\section{METHODS}

Wet-bulk density measurements used in this study were determined using the gamma ray attenuation porosity evaluator (GRAPE) on board the JOIDES Resolution. Details of the theory and operation of the GRAPE can be found in Boyce (1976). The GRAPE consists of a drive device that moves a gamma-ray source $\left({ }^{133} \mathrm{Ba}\right)$ and a shielded scintillation detector along the length of whole-round core sections ( $>80 \mathrm{~cm}$ length for its Leg 117 configuration). Gamma-ray attenuation in the cores is a function of sediment grain density and porosity, core-liner material, and core diameter. Wet-bulk density is calculated using assumed values of grain density, core-liner attenuation, and core diameter (Boyce, 1976). During Leg 117 the GRAPE was operated with a carriage speed of $0.76 \mathrm{~cm} / \mathrm{s}$ and a gamma-ray count period of $2 \mathrm{~s}$ followed by a $0.33 \mathrm{~s}$ break time between counts. This carriage speed and count interval resulted in each gamma-ray count sampling a $1.5-\mathrm{cm}$ interval of core. The sedimentary sections examined in this study are intervals for which the cored sediment completely filled the core liners. The GRAPE system was calibrated periodically with an aluminum standard, and a potential error of $1.5 \%$ (Boyce, 1976) is assumed for the measurements.

Because of the abundance of organic-rich sediments with low grain density, on the order of $2.40 \mathrm{~g} / \mathrm{cm}^{3}$, GRAPE wet-bulk density measurements were corrected for deviation of grain density from the value assumed in wet-bulk density computation $\left(2.60 \mathrm{~g} / \mathrm{cm}^{3}\right)$. The correction was based on grain density measurements for discrete samples taken at an average sampling interval of $3 \mathrm{~m}$. The average grain density of these samples was determined using a helium-displacement pycnometer using procedures described in Prell, Niitsuma, et al. (1989). Grain density data for each site were smoothed using a five-point moving average, and values for depths equivalent to the GRAPE-measurement depths were obtained by interpolation. Wet-bulk density was then recalculated using the interpolated grain density values.

In order to minimize wet-bulk density variation resulting from compaction, the trend of wet-bulk density increase with depth was removed from the GRAPE data by using published density gradients for typical deep-sea sediment sequences (Hamilton, 1976). A gradient of $1.5 \times 10^{-3} \mathrm{~g} / \mathrm{cm}^{3} / \mathrm{m}$ was subtracted from the Site 722 and Site 728 data sets. This gradient is close to Hamilton's gradients (for 0-100 mbsf) of $1.53 \times 10^{-3} \mathrm{~g} / \mathrm{cm}^{3} / \mathrm{m}$ for calcareous ooze, $1.30 \times 10^{-3} \mathrm{~g} / \mathrm{cm}^{3} / \mathrm{m}$ for terrigenous sediment, and $1.37 \times 10^{-3} \mathrm{~g} / \mathrm{cm}^{3} / \mathrm{m}$ for pelagic clay (Hamilton,
1976). Selection of a density gradient based on published values was chosen over determination of gradients at Sites 722 and 728 because of the downsection variation of wet-bulk density at these sites resulting from lithologic change.

Color variation in sediments recovered at Sites 722 and 728 was quantified by measuring changes in gray level on black-andwhite core photographs taken shortly after the cores were split and described. A Bio-Rad Model 620 video densitometer was used to generate the digital color data. The densitometer contains a 1,728-element CCD linear array detector and is capable of scanning a narrow (approximately $1 \mathrm{~mm}$ ) slot $20 \mathrm{~cm}$ long with a resolution of $132 \mu \mathrm{m}$. This resolution on the photographs is equivalent to a resolution greater than $1 \mathrm{~cm}$ on the core surface. The densitometer was operated in reflectance mode while scanning the core photographs, measuring the optical density of light reflected from the black-and-white images. Differences in light reflectance are measured by the densitometer in optical density units, with higher values of optical density representing darker shades of gray. Optical density data were corrected for differences in gray level among individual core photographs, that result from differences in film or photographic paper exposure and development, by scanning the gray-level scale placed next to core sections on the photographic stand and normalizing the gray-level range to an average value. Corrections were not made for exposure variation within individual photographs. Results of combining core sections to form composite sections and spectral analyses on depth-based series suggest that the exposure variation within photographs is minimal.

Upper Pliocene to Holocene sediments were recovered at Sites 722 and 728 in two holes drilled at each site. Recovery at both sites was high, averaging $100 \%$ for the $0-108 \mathrm{mbsf}$ interval at Site 722 and $102 \%$ for the $0-106$ mbsf interval at Site 728. Composite sections for both sites were constructed by interhole correlation of optical density and GRAPE data. Using this procedure gaps in recovery and intervals of coring disturbance were removed. The corrected core tops and intervals used in constructing composite sections are listed in Table 1.

\section{RESULTS}

\section{Characteristics of Bulk Density and Color Variation}

The cyclic variation of bulk density and sediment color is evident in depth profiles of wet-bulk density and optical density for Site 722 (Fig. 2) and Site 728 (Fig. 3). The length of the cycles at Site 722 varies with the dominant periodicities between $50 \mathrm{~cm}$ and $2 \mathrm{~m}$ (Fig. 2). Maximum amplitudes of the wet-bulk density and optical density cycles are $0.15 \mathrm{~g} / \mathrm{cm}^{3}$ and 0.30 , respectively. The interval between 75 and 95 mbsf at Site 722 , which encompasses a broad minimum in wet-bulk density, is characterized by very low variability in bulk density and highly variable optical density. At Site 728 the length of the wet-bulk density and optical density cycles is comparable to that at Site 722 (Fig. 3). The cycles at Site 728 are most pronounced in the upper $40 \mathrm{~m}$ of the section (upper Pleistocene) where maximum amplitudes of wet-bulk density and optical density variation are $0.20 \mathrm{~g} / \mathrm{cm}^{3}$ and 0.35 , respectively. Below 40 mbsf there is a reduction in amplitude of both bulk density and optical density variation.

Comparison of wet-bulk density with optical density reveals a weak correlation between bulk density and sediment color at both sites. A plot of wet-bulk density vs. optical density for Site 722 (Fig. 4) displays a general trend of decreasing bulk density with increasing darkness of sediment color (increasing optical density). The correlation between optical density and wet-bulk density is weak at Site 722 with the correlation coefficient equaling 0.47 . Sediments at Site 728 are characterized by a greater range in wet-bulk density and darker colors than sediments at 
Table 1. Corrected core tops and intervals for composite sections at Sites 722 and 728.

\begin{tabular}{|c|c|c|c|c|}
\hline $\begin{array}{c}\text { Core } \\
\text { no. }\end{array}$ & $\begin{array}{l}\text { ODP } \\
\text { core top } \\
\text { depth } \\
\text { (mbsf) }\end{array}$ & $\begin{array}{c}\text { Corrected } \\
\text { core top } \\
\text { depth } \\
\text { (mbsf) }\end{array}$ & $\begin{array}{l}\text { Interval } \\
\text { in ODP } \\
\text { depths } \\
\text { (m) }\end{array}$ & $\begin{array}{c}\text { Interval } \\
\text { in composite } \\
\text { section depths } \\
\text { (mbsf) }\end{array}$ \\
\hline $722 \mathrm{~B}-1 \mathrm{H}$ & 0 & 0 & $0-4.02$ & $0-4.02$ \\
\hline $722 \mathrm{~A}-1 \mathrm{H}$ & 0 & 1.67 & $2.35-5.38$ & $4.02-7.05$ \\
\hline $722 \mathrm{~B}-2 \mathrm{H}$ & 5.5 & 5.85 & $1.20-8.16$ & $7.05-14.01$ \\
\hline $722 \mathrm{~A}-2 \mathrm{H}$ & 9.8 & 11.48 & $2.53-5.31$ & $14.01-16.79$ \\
\hline $722 \mathrm{~B}-3 \mathrm{H}$ & 15.1 & 15.44 & $1.36-7.66$ & $16.80-23.10$ \\
\hline $722 \mathrm{~A}-3 \mathrm{H}$ & 19.4 & 21.00 & $2.11-4.96$ & $23.11-25.96$ \\
\hline $722 \mathrm{~B}-4 \mathrm{H}$ & 24.7 & 25.06 & $0.90-7.60$ & $25.96-32.66$ \\
\hline $722 \mathrm{~A}-4 \mathrm{H}$ & 29.0 & 30.63 & $2.03-5.60$ & $32.66-36.23$ \\
\hline $722 \mathrm{~B}-5 \mathrm{H}$ & 34.3 & 35.12 & $1.12-8.74$ & $36.24-43.86$ \\
\hline $722 \mathrm{~A}-5 \mathrm{H}$ & 38.6 & 40.84 & $3.04-3.80$ & $43.88-44.64$ \\
\hline $772 \mathrm{~B}-6 \mathrm{H}$ & 43.9 & 44.57 & $0.07-7.67$ & $44.64-52.24$ \\
\hline $722 \mathrm{~A}-6 \mathrm{H}$ & 48.2 & 50.17 & $2.07-4.85$ & $52.24-55.02$ \\
\hline 722B-7H & 53.2 & 53.87 & $1.15-7.96$ & $55.02-61.83$ \\
\hline $722 \mathrm{~A}-7 \mathrm{H}$ & 57.5 & 59.16 & $2.68-4.72$ & $61.84-63.88$ \\
\hline $722 \mathrm{~B}-8 \mathrm{H}$ & 62.9 & 63.76 & $0.12-7.76$ & $63.88-71.52$ \\
\hline $722 \mathrm{~A}-8 \mathrm{H}$ & 67.2 & 69.22 & $2.31-6.10$ & $71.53-75.32$ \\
\hline $722 \mathrm{~B}-9 \mathrm{H}$ & 72.5 & 73.93 & $1.40-8.72$ & $75.33-82.65$ \\
\hline $722 \mathrm{~A}-9 \mathrm{H}$ & 76.8 & 78.93 & $3.72-4.60$ & $82.65-83.53$ \\
\hline $722 \mathrm{~B}-10 \mathrm{H}$ & 82.7 & 82.85 & $0.68-8.51$ & $83.53-91.36$ \\
\hline $722 \mathrm{~A}-10 \mathrm{X}$ & 86.5 & 89.04 & $2.33-5.50$ & $91.37-94.54$ \\
\hline $722 B-11 X$ & 91.9 & 92.64 & $1.91-5.68$ & $94.55-98.32$ \\
\hline $722 A-11 X$ & 96.2 & 98.74 & $0-9.20$ & $98.74-107.94$ \\
\hline $728 \mathrm{~B}-1 \mathrm{H}$ & 0 & 0 & $0-0.67$ & $0-0.67$ \\
\hline $728 \mathrm{~A}-1 \mathrm{H}$ & 0 & 0.33 & $0.34-1.38$ & $0.67-1.71$ \\
\hline $728 \mathrm{~B}-2 \mathrm{H}$ & 1.2 & 1.20 & $0.52-9.43$ & $1.72-10.63$ \\
\hline $728 \mathrm{~A}-2 \mathrm{H}$ & 9.6 & 9.80 & $0.83-1.13$ & $10.63-10.93$ \\
\hline $728 \mathrm{~B}-3 \mathrm{H}$ & 10.7 & 10.43 & $0.50-9.12$ & $10.93-19.55$ \\
\hline $728 \mathrm{~A}-3 \mathrm{H}$ & 19.1 & 19.40 & $0.16-1.37$ & $19.56-20.77$ \\
\hline $728 \mathrm{~B}-4 \mathrm{H}$ & 20.1 & 20.49 & $0.28-8.94$ & $20.77-29.43$ \\
\hline $728 \mathrm{~A}-4 \mathrm{H}$ & 28.5 & 28.83 & $0.61-1.64$ & $29.44-30.47$ \\
\hline $728 \mathrm{~B}-5 \mathrm{H}$ & 29.6 & 30.01 & $0.47-8.97$ & $30.48-38.98$ \\
\hline $728 \mathrm{~A}-5 \mathrm{H}$ & 38.0 & 38.42 & $0.57-1.57$ & $38.99-39.99$ \\
\hline $728 \mathrm{~B}-6 \mathrm{H}$ & 39.1 & 39.50 & $0.49-8.80$ & $39.99-48.30$ \\
\hline $728 \mathrm{~A}-6 \mathrm{H}$ & 47.5 & 47.78 & $0.53-1.76$ & $48.31-49.54$ \\
\hline $728 \mathrm{~B}-7 \mathrm{H}$ & 48.6 & 49.05 & $0.49-8.46$ & $49.54-57.51$ \\
\hline $728 \mathrm{~A}-7 \mathrm{H}$ & 57.0 & 57.27 & $0.25-1.90$ & $57.52-59.17$ \\
\hline $728 \mathrm{~B}-8 \mathrm{H}$ & 58.1 & 58.71 & $0.47-8.95$ & $59.18-67.66$ \\
\hline $728 \mathrm{~A}-8 \mathrm{H}$ & 66.5 & 66.79 & $0.88-3.13$ & $67.67-69.92$ \\
\hline $728 \mathrm{~B}-9 \mathrm{H}$ & 67.7 & 68.33 & $1.60-8.48$ & $69.93-76.81$ \\
\hline $728 \mathrm{~A}-9 \mathrm{H}$ & 76.1 & 76.41 & $0.40-1.84$ & $76.81-78.25$ \\
\hline $728 B-10 X$ & 77.3 & 77.91 & $0.34-8.26$ & $78.25-86.17$ \\
\hline $728 \mathrm{~A}-10 \mathrm{X}$ & 85.7 & 86.02 & $0.15-2.38$ & $86.17-88.40$ \\
\hline $728 B-11 X$ & 86.9 & 87.51 & $0.89-8.53$ & $88.40-96.04$ \\
\hline $728 \mathrm{~A}-11 \mathrm{X}$ & 95.3 & 95.84 & $0.20-2.55$ & $96.04-98.39$ \\
\hline $728 B-12 X$ & 96.5 & 97.11 & $1.28-9.55$ & $98.39-106.66$ \\
\hline
\end{tabular}

Site 722 (Fig. 5). At Site 728 a trend of decreasing bulk density with increasing optical density is displayed for the upper $85 \mathrm{~m}$ of the section. The correlation coefficient for optical density and wet-bulk density in this interval is 0.57 . Between $85 \mathrm{mbsf}$ and the base of the section studied (106 mbsf), sediments lie in a relatively restricted field, bounded by wet-bulk density values of 1.45 and $1.65 \mathrm{~g} / \mathrm{cm}^{3}$ and optical density values of 0.64 and 1.08 (Fig. 5). In this interval no apparent relation between bulk density and sediment color exists. The abundance of radiolarians and diatoms below $85 \mathrm{mbsf}$ and their effect of decreasing bulk density is the likely cause for the breakdown in the relationship between sediment color and wet-bulk density.

Insight into lithologic controls on wet-bulk density and optical density is provided by comparison of these data with calcium carbonate and organic carbon concentration data. The calcium carbonate and organic carbon data are shipboard measurements obtained during Leg 117 using a Coulometrics Carbonate Carbon Apparatus and a Coulometrics Total Carbon Apparatus (Prell, Niitsuma, et al., 1989). Organic carbon was determined as the difference between total carbon and carbonate carbon. Calcium carbonate data are from samples taken with a spacing of approximately $3 \mathrm{~m}$ for the entire sections at both sites. Organic carbon determinations were made less frequently, and as a consequence, only five values are available at Site 722 and 28 values at Site 728 . At Site 728 the organic carbon data are not uniformly spaced. Spacing of the data is at approximately $10-\mathrm{m}$ intervals above $50 \mathrm{mbsf}$ and $3-\mathrm{m}$ intervals between 50 and 106 mbsf.

A plot of wet-bulk density vs. calcium carbonate concentration (Fig. 6) displays no apparent relationship between wet-bulk density and calcium carbonate at either Site 722 or Site 728 . Variation in calcium carbonate abundance in Owen Ridge sediments has been shown to be the product of dilution by terrigenous sediment components (Murray et al., 1988; Clemens and Prell, this volume). Because of the strong inverse relationship between calcareous and terrigenous components (Clemens and Prell, this volume), variation in calcium carbonate concentration can be used as a measure of variation of terrigenous sediment constituents. Density profiles for typical deep-sea calcareous oozes and terrigenous sediments are nearly overlapping between the seafloor and 100 mbsf (Hamilton, 1976), and as a consequence little change in wet-bulk density would be expected as the relative abundance of terrigenous and calcareous sediment components varies. Lack of a relationship between wetbulk density and calcium carbonate concentration may also reflect effects of grain-size variation. In the upper several hundred meters of typical sedimentary sequences a direct relationship between grain size and wet-bulk density (increasing bulk density with increasing grain size) exists (Hamilton, 1974). For Owen Ridge sediments grain size of terrigenous components has been shown to vary independently from variation in the abundance of terrigenous components (Clemens and Prell, this volume). Scatter in the plot of wet-bulk density vs. calcium carbonate concentration in part may also reflect varying abundance of organic matter and siliceous microfossils. Small amounts of both of these constituents can significantly decrease wet-bulk density.

Comparison of wet-bulk density data with organic carbon concentration data indicates that wet-bulk density varies as a function of the abundance of organic matter at Sites 722 and 728. At both sites wet-bulk density decreases with increasing organic carbon concentration (Fig. 6). Although organic-carbon data from Site 722 are limited, the pattern indicated in Figure 6 is that data from Site 722 lie in a field separate from that of data from Site 728. Smear-slide descriptions (Prell, Niitsuma, et al., 1989) indicate that sediments from Site 722 are slightly finer grained than those at Site 728 . Lower wet-bulk density of Site 722 sediments than that of Site 728 sediments at comparable organic carbon concentrations probably reflects the finer grain size at Site 722 .

Changes in calcium carbonate and organic matter abundance have a more straightforward effect on sediment color than they have on wet-bulk density. Optical density displays distinct trends of increasing with increasing terrigenous sediment abundance (decreasing calcium carbonate concentration) (Fig. 6) and increasing organic carbon concentration (Fig. 6). The relationship between organic carbon concentration and optical density shown in Figure 6 fits the well-established association between sediment color and organic carbon concentration in fine-grained sediments, which has been characterized as a trend in which modest organic carbon contents $(<1 \%)$ impart a strong dark color, and increasing organic carbon concentration produces a consistent increase in color darkness, but with considerable spread (Potter et al., 1980). Patterns of color variation as a function of calcium carbonate and organic matter abundance in part are related in that a general inverse relationship between calcium carbonate and organic carbon concentrations exists in Owen Ridge and Oman margin sediments (Prell, Niitsuma, et al., 1989). For the upper Pliocene to Holocene sections at Sites 722 and 728 the correlation between organic carbon concentra- 


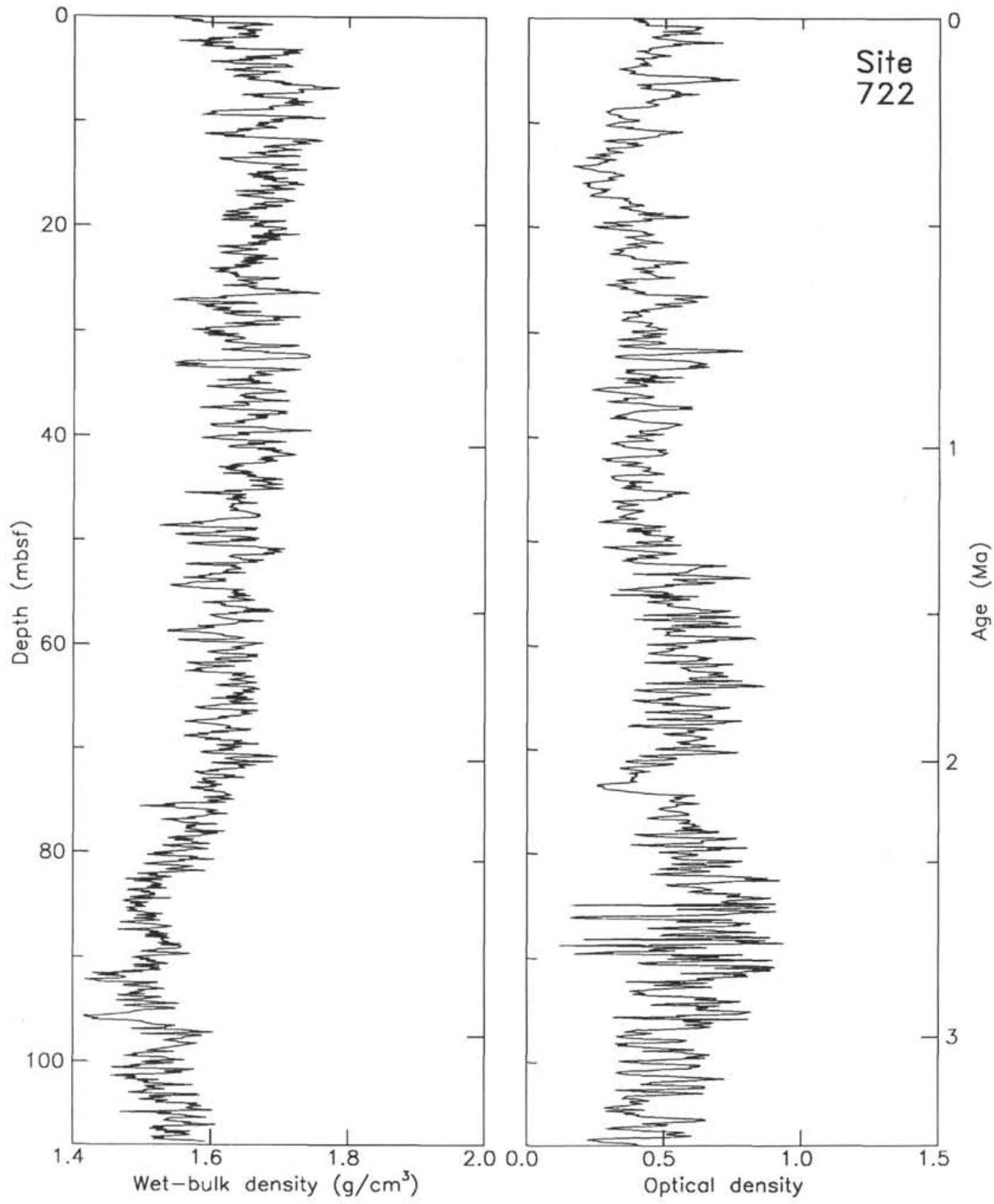

Figure 2. Profiles of corrected GRAPE wet-bulk density and optical density for Site 722. The profiles are based on 10$\mathrm{cm}$-block averages of the data.

tion and calcium carbonate concentration is weak, with a correlation coefficient of 0.52 for the combined data sets.

\section{Time Series of Wet-bulk Density and Optical Density}

Depth records of wet-bulk density and optical density were converted to time series using a combination of oxygen isotope, biostratigraphic, and paleomagnetic data. Age datums used for the time series are listed in Table 2 (Site 722) and Table 3 (Site 728). Oxygen isotope data were used as age control for the upper Pleistocene sections and were provided by S. Clemens (pers. comm., 1989) for Site 722 and D. Kroon (pers. comm., 1989) for Site 728. The late Pleistocene age model for Site 722 reflects further refinement by orbital tuning (Clemens and Prell, this volume). Age control for sections older than late Pleistocene was based primarily on biostratigraphic datums at Site 722 and a combination of paleomagnetic and biostratigraphic datums at Site 728 .

Detailed time series of optical density (Fig. 7) and wet-bulk density (Fig. 8), provided by high-resolution age control for upper Pleistocene sections at Sites 722 and 728, allow recognition of some of the processes affecting changes in sediment color and bulk density on the Owen Ridge and Oman margin. The late Pleistocene time series of optical density for Site 722 (Fig. 7) displays a distinct pattern of higher optical density (darker sediment colors) during even-numbered oxygen isotope stages (glacial periods). The concentration of darker colored sediment in glacial periods at Site 722 is even more apparent when the optical density is averaged over the time intervals represented by 

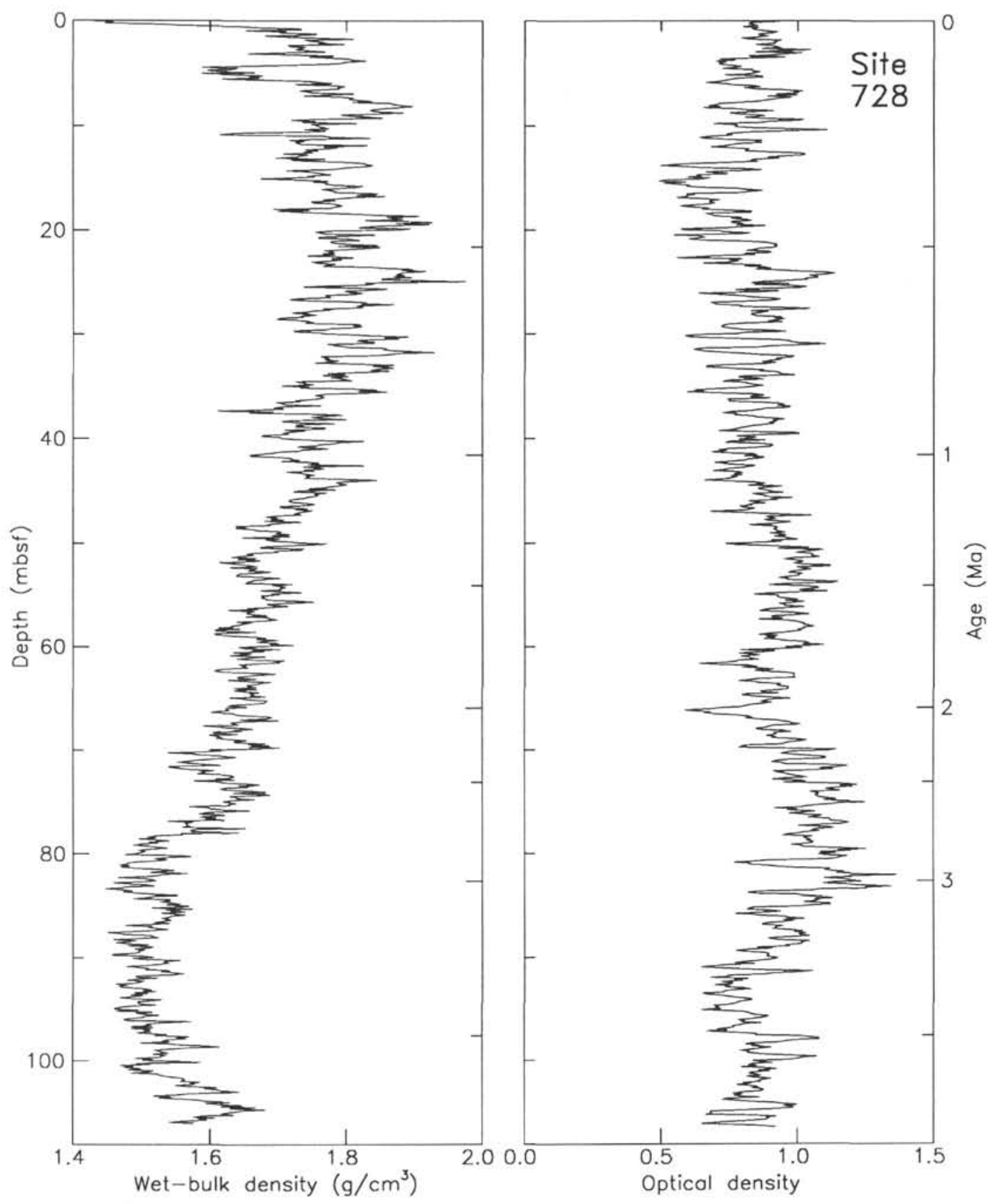

Figure 3. Profiles of corrected GRAPE wet-bulk density and optical density for Site 728. The profiles are based on 10$\mathrm{cm}$-block averages of the data.

the oxygen isotope stages (Fig. 9). This pattern of color variation is consistent with the inverse relationship between optical density and calcium carbonate content and the determination of higher accumulation rates of terrigenous sediment components during glacial periods (Murray et al., 1988; Clemens and Prell, this volume). The correlation of dark sediment intervals and even-numbered oxygen isotope stages is not as strong at Site 728 as it is at Site 722 (Figs. 7 and 9). Upper Pleistocene sediments at Site 728 are darker than those at Site $\mathbf{7 2 2}$, as a consequence of greater abundance of terrigenous components and organic matter, and display a greater range and variability in optical density.

Wet-bulk density time series for upper Pleistocene sediments at Sites 722 and 728 (Fig. 8) display patterns that are not as straightforward as those of optical density time series for these sediments. An association of higher bulk density and glacial intervals exists for oxygen isotope stages $1-10$ at Site 722 and the entire upper Pleistocene section at Site 728 , with the exception of stage 14. At Site 722 sediments older than stage 10 are characterized by low contrast in wet-bulk density between oxygen isotope stages. These patterns of density variation can be seen in the time series (Fig. 8) but are again more clearly evident in a plot of average wet-bulk density for the oxygen isotope stages (Fig. 9). Upper Pleistocene sediments at Site 728 display a greater range in bulk density than those at Site 722 and a greater contrast in wet-bulk density between adjacent stages than that of sediments at Site 722 (Figs. 8 and 9). The correlation of higher wet-bulk density and glacial periods is interesting when compared with the general pattern of dark sediment intervals corre- 


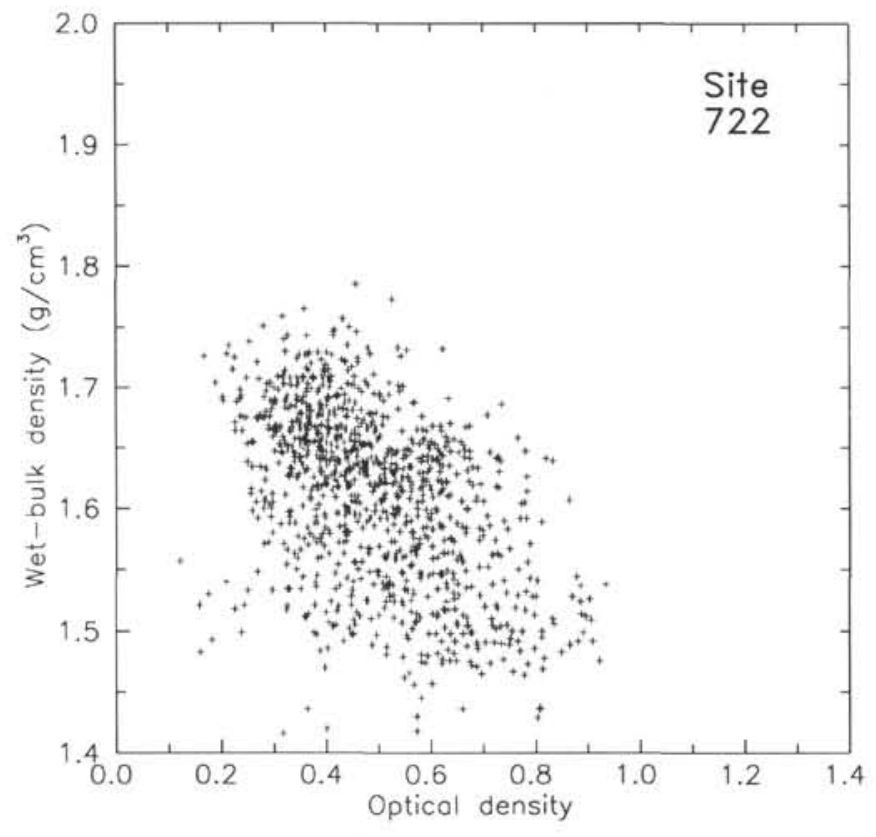

Figure 4. Wet-bulk density and optical density for Site 722. Wet-bulk density and optical density data are $10-\mathrm{cm}$-block averages.

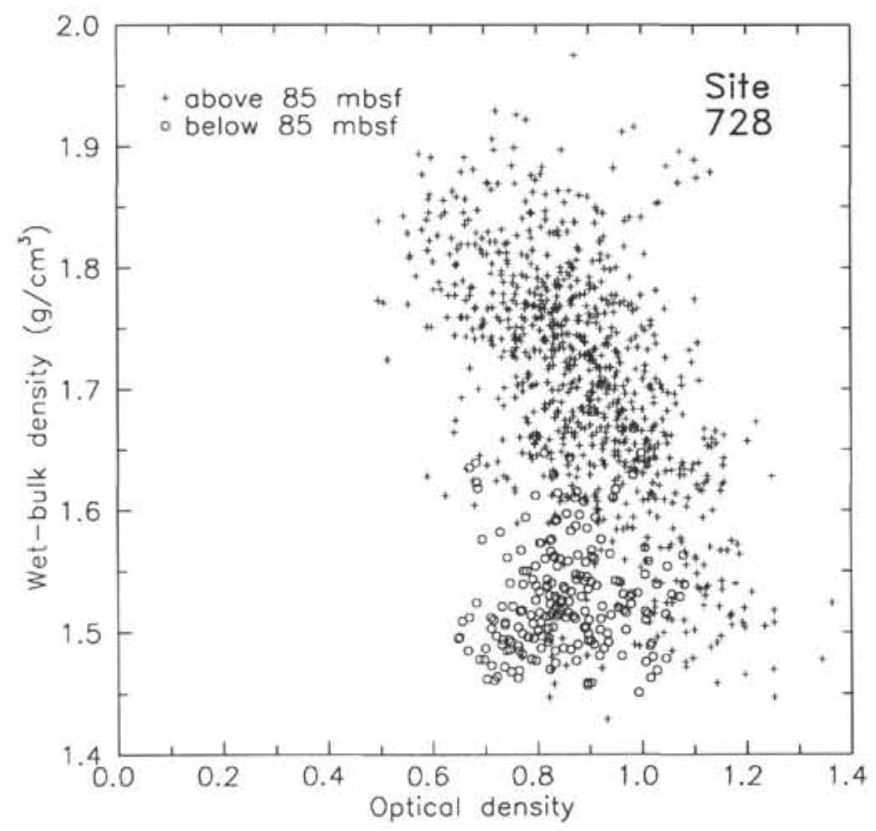

Figure 5. Wet-bulk density and optical density for Site 728. Wet-bulk density and optical density data are 10-cm-block averages.

sponding with glacial periods because it is opposite the general trend of decreasing wet-bulk density with increasing sediment darkness (Figs. 4 and 5).

\section{Spectral Analysis}

Characteristics of the cyclicity of wet-bulk density and sediment color at Sites 722 and 728 were examined by spectral analysis of time series spanning the past $3.4 \mathrm{~m} . \mathrm{y}$. Spectral analysis was performed according to standard techniques described in Jenkins and Watts (1968) and Priestley (1981). At both sites changes in the characteristics of the cyclic behavior of optical density and wet-bulk density were examined by subdividing the $3.4 \mathrm{~m} . \mathrm{y}$. records into four intervals: $0-0.73 \mathrm{Ma} ; 0.73-1.66 \mathrm{Ma}$; 1.66-2.47 Ma; and 2.47-3.4 Ma. This subdivision was based on distribution of the age datums and an attempt to obtain intervals of nearly equal length. Data sets used in spectral analyses were obtained by interpolating the wet-bulk density and optical density time series at a spacing approximately equal to the average sample spacing of the wet-bulk density time series (the lower resolution series). This interpolation resulted in sample intervals of approximately $700 \mathrm{yr}$ for the $0-0.73 \mathrm{Ma}$ interval, 800 $\mathrm{yr}$ for the 1.66-2.47 Ma interval, and $900 \mathrm{yr}$ for the $0.73-1.66$ $\mathrm{Ma}$ and 2.47-3.4 Ma intervals. In addition to calculating variance spectra for wet-bulk density and optical density time series at Sites 722 and 728, the coherency of these time series was determined by cross spectral analysis. Results of the spectral and cross spectral analyses are shown in Figure 10 (Site 722) and Figure 11 (Site 728) and summarized in Table 4.

Variance spectra of wet-bulk density and optical density (Figs. 10 and 11) display concentration of variance at periodicities corresponding to those of the earth's orbital parameters of eccentricity (100 k.y.), obliquity (41 k.y.), and precession (23 and 19 k.y.). Differences in the sharpness of the spectral peaks among spectra for the different time periods in part reflects the accuracy of the age datums used to generate the time series. This difference is particularly apparent when comparing spectra for the late Pleistocene interval at Site 722 (Fig. 10A), the interval with the most detailed chronology (Table 2), with spectra for the other time intervals at both sites. The late Pleistocene age model for Site 722 reveals that sedimentation rates during the deposition of dark layers are approximately twice as large as those associated with light layers. For intervals at Sites 722 and 728 where age datums are more widely spaced, inaccuracies in the variance spectra may reflect unrecognized fluctuations in sedimentation rate on the scale of those that characterize the upper Pleistocene section at Site 722 .

Spectra shown in Figures 10 and 11 indicate that at both Sites 722 and 728 , wet-bulk density and optical density time series display significant concentration of variance at approximately the 41-k.y. periodicity. Spectral peaks at 41 k.y. are minor or absent only for spectra of wet-bulk density for the $0.73-$ 1.66 Ma interval at both Sites 722 and 728 (Figs. 10B and 11B) and for spectra of optical density for the intervals $0.73-1.66$ $\mathrm{Ma}, 1.66-2.47 \mathrm{Ma}$, and 2.47-3.4 Ma at Site 728 (Figs. 11B, 11C, and 11D). Despite concentration of variance in the obliquity frequency band, significant coherence between wet-bulk density and optical density exists only for the 1.66-2.47 Ma interval at Site 722 (Fig. 10C).

Concentration of variance at the precessional periodicities of 23 and 19 k.y., or in the interval between these periodicities, is common to spectra for all of the time intervals examined at Sites 722 and 728 (Figs. 10 and 11, Table 4), with the exception of the optical density spectrum for the 2.47-3.4 Ma interval at Site 722 (Fig. 10D). In contrast to characteristics of coherency spectra at the obliquity periodicity, significant coherence is present at the precession frequency band for most of the time intervals at Sites 722 and 728 . Significant coherence between wet-bulk density and optical density at 23-19 k.y. periodicities is absent only for the 1.66-2.47 Ma and 2.47-3.4 Ma intervals at Site 728 (Figs. $11 \mathrm{C}$ and 11D).

Spectral peaks at the eccentricity periodicity vary more among spectra for the four time intervals at Sites 722 and 728 than those associated with the obliquity and precession frequency bands. Distinct peaks at approximately $100-k . y$. periodicities in both wet-bulk density and optical density spectra are present only for the $0-0.73 \mathrm{Ma}$ and $1.66-2.47 \mathrm{Ma}$ intervals at Site 722 (Figs. 10A and 10C) and the 1.66-2.47 Ma interval at Site 728 

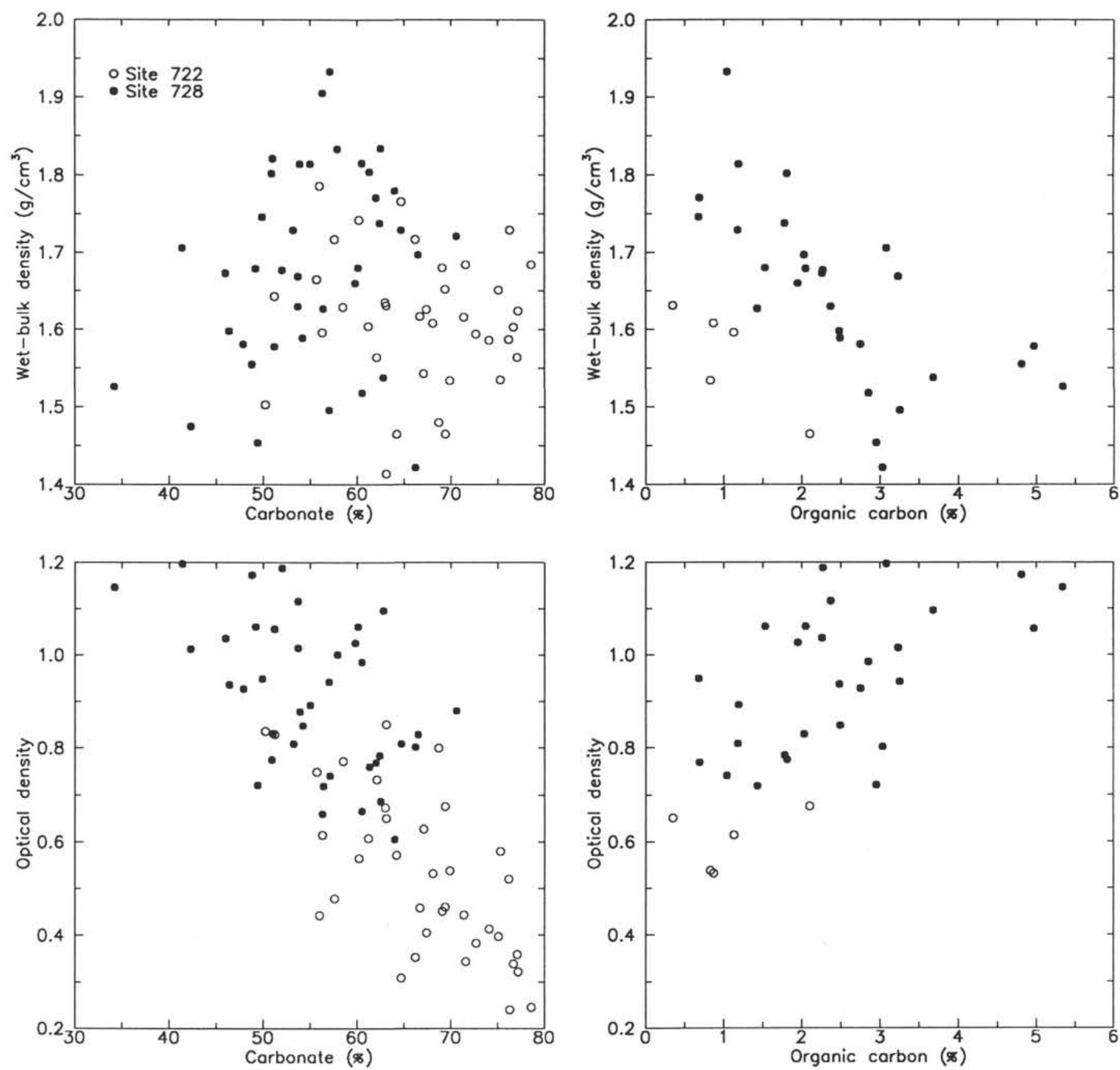

Figure 6. Variation of wet-bulk density and optical density with carbonate and organic carbon concentration for Site 722 and Site 728.

(Fig. 11C). Spectra for the other time intervals at both sites are characterized by peaks at higher periodicities (131 and $171 \mathrm{k.y}$. for $0.73-1.66 \mathrm{Ma}$ at Site 722 , Fig 10B), presence of only a wetbulk density or-optical density peak at 100 k.y., or presence of a broad shoulder that extends from the 100 k.y. to higher periodicities. The eccentricity spectral peak is typically the dominant peak in the spectra where it is present (Figs. 10 and 11). Significant coherence between wet-bulk density and optical density at the $100-\mathrm{k} . \mathrm{y}$. periodicity is present only for the $0-0.73 \mathrm{Ma}$ and 1.66-2.47 Ma intervals at Site 722 (Figs. 10A and 10C) and the 2.47-3.4 Ma interval at Site 728 (Fig. 11D).

In addition to concentration of variance at the primary Milankovitch periodicities, wet-bulk density and optical density spectra for the four time intervals at Sites 722 and 728 display peaks of varying significance with periodicities ranging between 53 and 64 k.y. and between 25 and 33 k.y. (Figs. 10 and 11). Spectral peaks within these ranges are also present in spectra for late Pleistocene time series of terrigenous-component grain size at Site 722 and have been interpreted to be associated with combinations (cross products) of the primary Milankovitch frequencies (Clemens and Prell, this volume).

At Sites 722 and 728 consistent trends in the relative strength of spectral peaks in wet-bulk density and optical density spectra or differences between wet-bulk density and optical density spectra are not readily apparent. Where distinct 100 k.y. peaks are present they contain the highest concentration of variance, and with the exceptions noted, a strong $41 \mathrm{k} . \mathrm{y}$. signal is a feature of most of the spectra. Wet-bulk density and optical density spec- 
Table 2. Age model for Site 722.

\begin{tabular}{|c|c|c|}
\hline $\begin{array}{l}{ }^{\mathrm{a}} \text { Depth } \\
\text { (mbsf) }\end{array}$ & $\begin{array}{c}\text { Age } \\
(\mathrm{Ma})\end{array}$ & Event \\
\hline 0.01 & 0.006 & $\mathrm{~b}_{1.1}$ \\
\hline 1.01 & 0.0178 & 2.22 \\
\hline 3.31 & 0.065 & 4.2 \\
\hline 3.81 & 0.080 & 5.1 \\
\hline 4.21 & 0.099 & 5.3 \\
\hline 4.71 & 0.122 & 5.5 \\
\hline 5.89 & 0.135 & 6.2 \\
\hline 7.96 & 0.171 & 6.5 \\
\hline 8.46 & 0.183 & 6.6 \\
\hline 9.26 & 0.2184 & \\
\hline 10.26 & 0.238 & 7.5 \\
\hline 10.86 & 0.249 & 8.2 \\
\hline 12.06 & 0.269 & 8.4 \\
\hline 12.46 & 0.287 & 8.5 \\
\hline 12.86 & 0.299 & 8.6 \\
\hline 13.66 & 0.331 & 9.3 \\
\hline 14.36 & 0.341 & 10.2 \\
\hline 15.85 & 0.375 & 11.2 \\
\hline 16.85 & 0.405 & 11.3 \\
\hline 17.05 & 0.423 & 12.0 \\
\hline 17.65 & 0.434 & 12.2 \\
\hline 18.85 & 0.461 & 12.33 \\
\hline 19.25 & 0.471 & 12.4 \\
\hline 19.85 & 0.491 & 13.12 \\
\hline 20.25 & 0.513 & 13.2 \\
\hline 20.75 & 0.524 & 14.0 \\
\hline 21.05 & 0.538 & 14.2 \\
\hline 21.25 & 0.552 & 14.3 \\
\hline 21.45 & 0.563 & 14.4 \\
\hline 21.65 & 0.574 & 15.1 \\
\hline 22.05 & 0.596 & 15.3 \\
\hline 22.85 & 0.617 & 15.5 \\
\hline 23.25 & 0.628 & 16.22 \\
\hline 24.65 & 0.656 & 16.4 \\
\hline 25.67 & 0.689 & 17.3 \\
\hline 26.67 & 0.700 & 18.23 \\
\hline 27.47 & 0.721 & 18.4 \\
\hline 28.17 & 0.731 & 19.1 \\
\hline 29.07 & 0.756 & 20.24 \\
\hline 31.47 & 0.79 & \\
\hline 33.07 & 0.8175 & \\
\hline 33.47 & 0.8399 & \\
\hline 34.57 & 0.8619 & \\
\hline 35.73 & 0.8814 & \\
\hline 36.93 & 0.8895 & \\
\hline 37.83 & 0.9215 & \\
\hline 38.53 & 0.9478 & \\
\hline 39.23 & 0.9705 & \\
\hline 39.93 & 0.9884 & \\
\hline 41.33 & 1.004 & \\
\hline 42.33 & 1.015 & \\
\hline 44.88 & 1.10 & LAD Gephyrocapsa "large" \\
\hline 55.38 & 1.45 & LAD Calcidiscus macintyrei \\
\hline 69.55 & 1.90 & LAD Discoaster brouweri \\
\hline 77.43 & 2.40 & LAD Discoaster pentaradiatus \\
\hline 102.67 & 3.15 & \\
\hline 108.56 & 3.50 & LAD Reticulofenestra pseudoumbilica \\
\hline
\end{tabular}

tra for the $0.73-1.66 \mathrm{Ma}$ interval at Site 722 (Fig. 10B) display a greater concentration of variance at the precession periodicities than at the obliquity periodicity; however, in the other spectra the relative strength of the 23 and 19 k.y. peaks varies from being nearly equal to clearly less than that of the $41 \mathrm{k} . \mathrm{y}$. peaks. In comparing the wet-bulk density and optical density spectra there is no consistent relationship in changes in the relative strength of the spectral peaks among the spectra. For example, for time intervals where the strength of the $41 \mathrm{k} . \mathrm{y}$. spectral peak clearly differs between optical density and wet-bulk density spectra, there is not a consistent change in the relative strengths of spectral peaks at 23 and 19 k.y. periodicities.
Table 3. Age model for Site 728.

\begin{tabular}{rll}
\hline a Depth & Age & \\
(mbsf) & (Ma) & \\
\hline & & \multicolumn{1}{c}{ Event } \\
\hline 0.68 & 0.012 & b 2.0 \\
1.82 & 0.024 & 3.0 \\
3.56 & 0.059 & 4.0 \\
3.74 & 0.064 & 4.2 \\
4.22 & 0.071 & 5.0 \\
4.40 & 0.080 & 5.1 \\
4.88 & 0.100 & 5.3 \\
5.54 & 0.122 & 5.5 \\
5.66 & 0.128 & 6.0 \\
10.16 & 0.186 & 7.0 \\
10.33 & 0.195 & 7.1 \\
10.73 & 0.216 & 7.3 \\
11.75 & 0.238 & 7.5 \\
11.83 & 0.245 & 8.0 \\
14.09 & 0.303 & 9.0 \\
14.29 & 0.310 & 9.1 \\
14.91 & 0.330 & 9.3 \\
15.15 & 0.339 & 10.0 \\
16.50 & 0.362 & 11.0 \\
17.75 & 0.405 & 11.3 \\
17.95 & 0.423 & 12.0 \\
20.65 & 0.478 & 13.0 \\
22.00 & 0.524 & 14.0 \\
22.66 & 0.565 & 15.0 \\
24.03 & 0.620 & 16.0 \\
25.38 & 0.659 & 17.0 \\
26.76 & 0.689 & 18.0 \\
28.13 & 0.726 & 19.0 \\
28.49 & 0.736 & 20.0 \\
29.45 & 0.763 & 21.0 \\
32.59 & 0.820 & LAD Reticulofenestra sp. A \\
40.81 & 0.970 & \\
44.07 & 1.10 & LAD Gephyrocapsa "large" \\
52.82 & 1.45 & LAD Calcidiscus macintyrei \\
64.52 & 1.90 & LAD Discoaster brouweri \\
72.59 & 2.47 & Matuyama/Gauss \\
80.57 & 2.92 & Top Kaena \\
87.22 & 3.18 & Bottom Mammoth \\
94.33 & 3.40 & Gauss/Gilbert \\
96.59 & 3.47 & LAD Sphenolithus abies \\
124.11 & 3.88 & Top Cochiti \\
& &
\end{tabular}

a Depth in composite section.

${ }^{b}$ Oxygen isotope data from Steens et al. (this volume).

\section{DISCUSSION}

\section{Origin of Wet-Bulk Density and Sediment Color Variation}

Wet-bulk density varies as a function of porosity and grain density, displaying an inverse relationship with porosity and a direct relationship with grain density. Both of these parameters vary with sediment lithology. The grain density of sediment components common in Oman margin and Owen Ridge sediments falls into two ranges: (1) $2.55-2.75 \mathrm{~g} / \mathrm{cm}^{3}$ (calcite, quartz, feldspar, and clay minerals) and (2) $2.0 \mathrm{~g} / \mathrm{cm}^{3}$ or less (organic matter and biogenic silica). Published values for the grain density of marine organic solids are uncommon; however, the density of these materials should be comparable to that of terrestrial maceral material, which typically ranges from 1.0 to $1.5 \mathrm{~g} /$ $\mathrm{cm}^{3}$ (Robert, 1988). The grain density of biogenic silica has been determined to be in the range of $1.70-2.05 \mathrm{~g} / \mathrm{cm}^{3}$ (Hurd and Theyer, 1977). Because of the very low density of organic matter and biogenic silica, small amounts of these components can significantly lower the bulk density. Dependence of porosity on lithology is related to the size of the pore spaces in the sediment and the amount of water that is adsorbed onto particles. Trends of increasing porosity with increasing sorting and decreasing grain size are well-established for marine sediments (Hamilton, 1974; Bryant et al., 1981). Porosity increases with increasing 


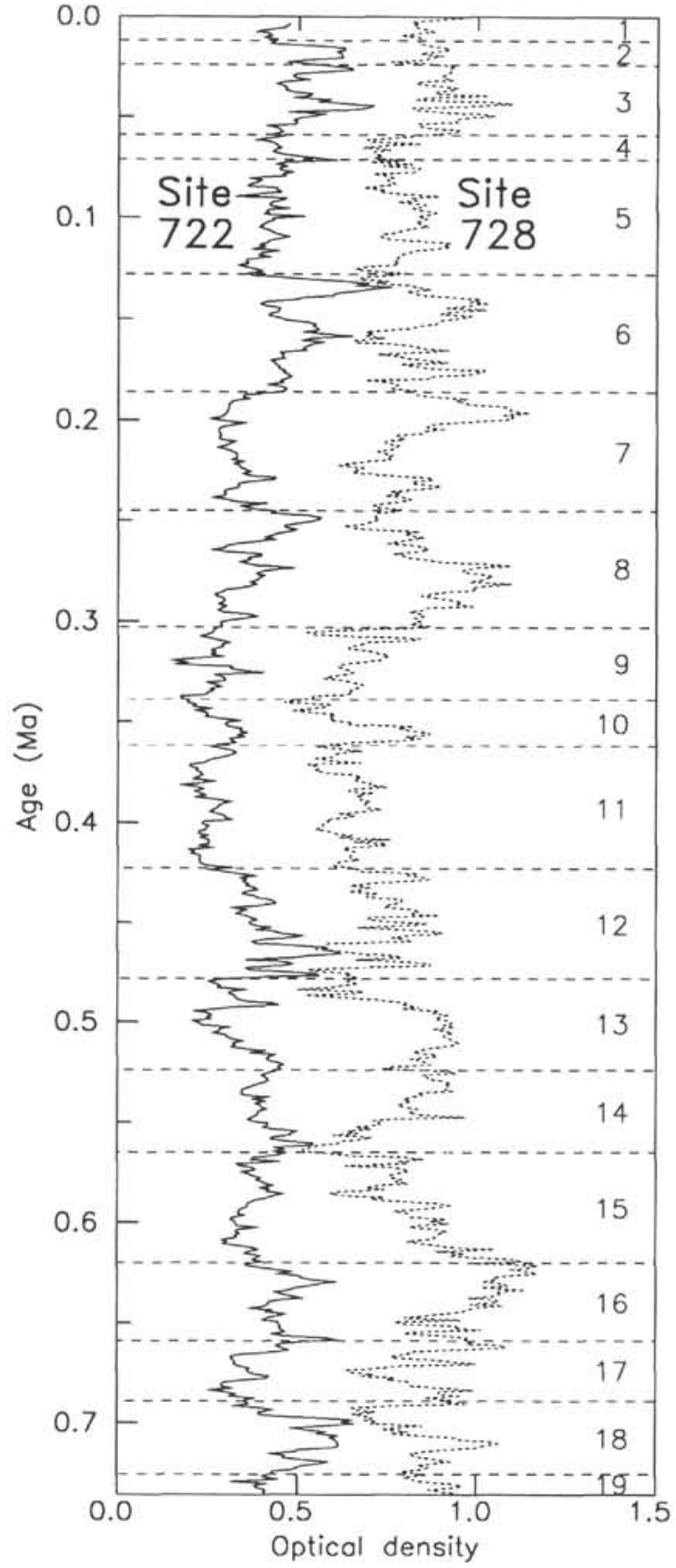

Figure 7. Time series of optical density for the late Pleistocene (0-0.736 Ma) at Site 722 (solid line) and Site 728 (dashed line). The optical density data are 1000-yr-block averages. Oxygen isotope stage boundaries are indicated by dashed horizontal lines. Stages are labeled by numbers on the right.

abundance of clay-sized particles because their high specific surface (surface area per unit mass) results in greater adsorption of water on particle surfaces and because they tend to be arranged in open, flocculated fabrics (Callaway and Busch, this volume). Composition of the clay fraction influences porosity as a consequence of the dependence of specific surface and fabric on clay mineralogy. Organic matter abundance affects porosity through formation of clay-organic aggregates and the porous fabrics associated them (Pusch, 1973; Reimers, 1982) and through adsorption of water on the surface of the organic matter (Pusch, 1973). The abundance of siliceous microfossils has a significant

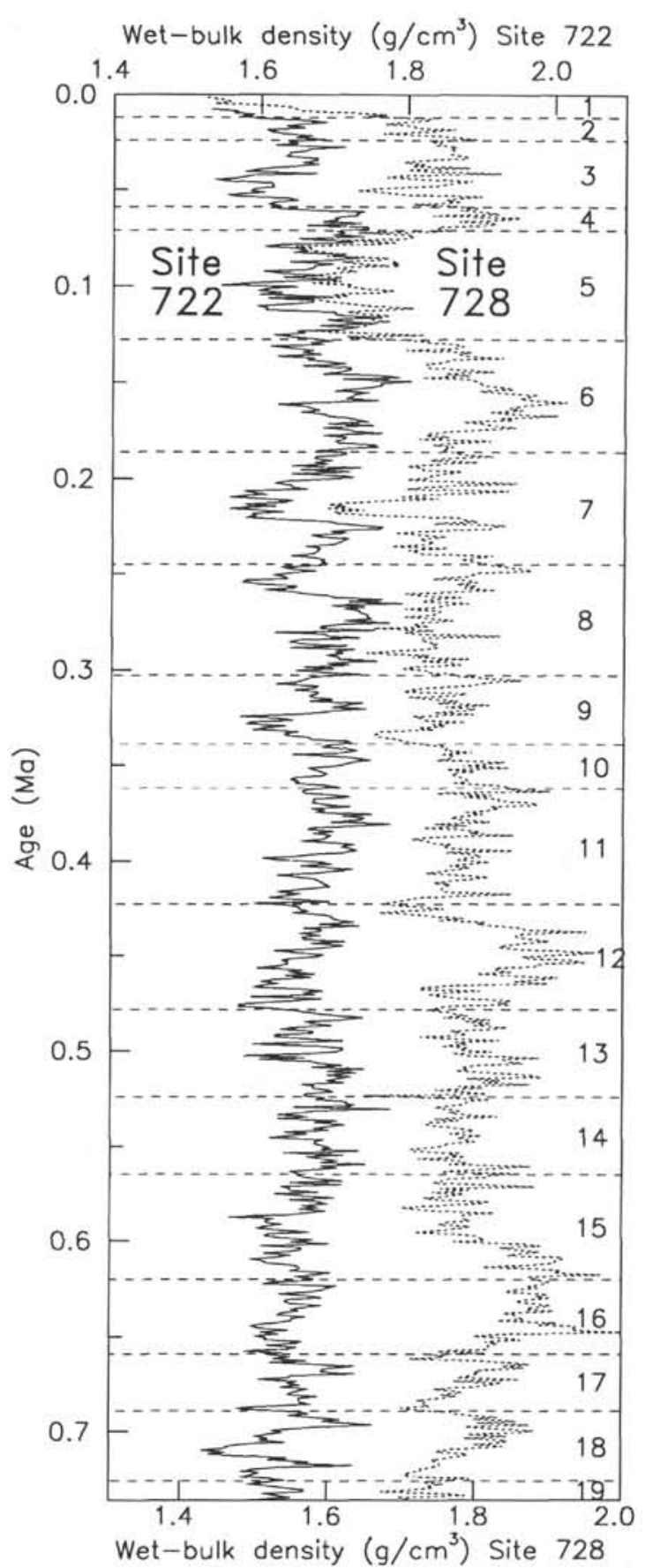

Figure 8. Time series of wet-bulk density for the late Pleistocene (0$0.736 \mathrm{Ma}$ ) for Site 722 (solid line) and Site 728 (dashed line). The wetbulk density data are 1000-yr-block averages. Oxygen isotope stage boundaries are indicated by dashed horizontal lines. Stages are labeled by numbers on the right. Note that the density axes for the two sites (top: Site 722, bottom: Site 728 ) are offset by $0.4 \mathrm{~g} / \mathrm{cm}^{3}$ to limit overlap.

effect on porosity as a consequence of the void space within the biogenic particles and the tendency of the microfossils to be arranged in an open structural fabric.

The data available indicate that wet-bulk density variation at Sites 722 and 728 is strongly influenced by the abundance of organic matter (Fig. 6). A positive correlation between organic carbon concentration and biogenic silica abundance at Site 728 (Prell, Niitsuma, et al., 1989) most likely augments the relation- 


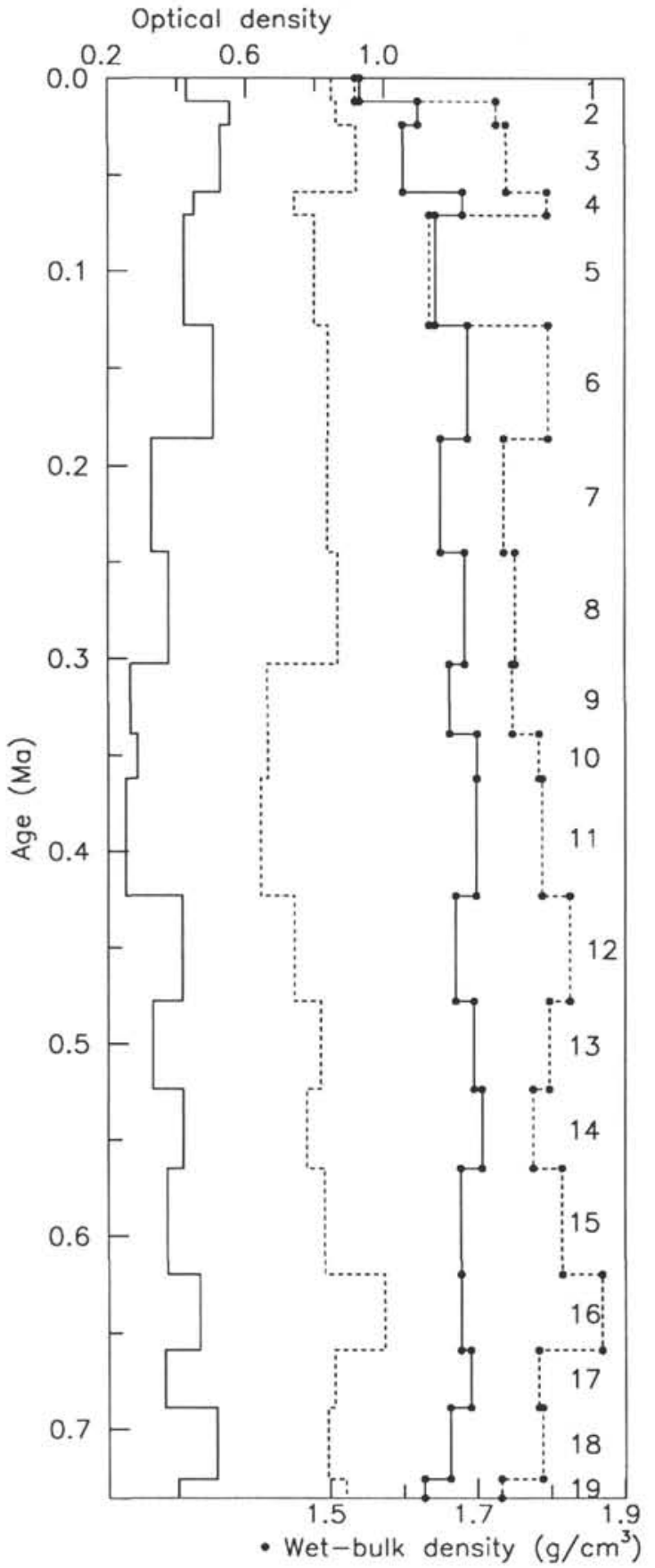

Figure 9. Averages of optical density (lines) and wet-bulk density (lines and dots) for oxygen isotope stages 1-19 (0-0.736 Ma) at Site 722 (solid lines) and Site 728 (dashed lines). Stages are labeled by numbers on the right.

ship between bulk density and organic carbon concentration. The extent to which the biogenic silica concentration affects wet-bulk density at both sites cannot be evaluated because of the lack of quantitative data for this sediment component. Other factors influencing the wet-bulk density of sediments at Sites 722 and 728 are more speculative. The lack of a relationship between wet-bulk density and calcium carbonate concentration in part is related to similarity of the grain density of calcareous components and terrigenous components, the primary dilutant of the calcareous components. Grain-size variation may contribute to changes in bulk density at Sites 722 and 728; however, additional grain-size data are needed to confirm this potential relationship. The lack of a relationship between the size and abundance terrigenous sediments, which has been documented for upper Pleistocene sediments at Site 722 (Clemens and Prell, this volume), most likely contributes to the lack of a relationship between wet-bulk density and calcium carbonate concentration (Fig. 6). Differences in clay mineralogy exist between dark and light layers in Owen Ridge sediments, with dark layers characterized by $5 \%-10 \%$ more palygorskite relative to light layers (P. Debrabant, pers. comm., 1988). The effect of this variation on changes in wet-bulk density is probably minor.

Color variation of fine-grained sediments is primarily controlled by two factors: (1) oxidation state of iron, the $\mathrm{Fe}^{3+} / \mathrm{Fe}^{2+}$ ratio, and (2) amount of organic carbon present (Potter et al., 1980). These two factors are partly related in that presence of small amounts of organic matter favors the reduced form of iron $\left(\mathrm{Fe}^{2+}\right)$. Potter et al. (1980) have divided color variation of fine-grained sediments into two series, a red to purple to greenish gray series based on $\mathrm{Fe}^{3+} / \mathrm{Fe}^{2+}$ and a greenish gray to gray to black series based on organic carbon content. Sediments lacking iron compounds or organic matter as pigments display colors associated with other constituents. These sediments are characterized by bluish colors, pale blue or pale blue green, where carbonate minerals are abundant (Potter et al. 1980) and green colors where the true color of clay minerals shows through (Blatt, 1982).

Colors of upper Pliocene to Holocene sediments examined at Sites 722 and 728 range from pale greenish gray to dark olive gray. This range of colors falls within the color series associated with variation in organic carbon content. Green and olive colors displayed by the sediments may reflect variation in terrigenous clay abundance modifying or augmenting the organic carbon color series. Colors spanning the range of the $\mathrm{Fe}^{3+} / \mathrm{Fe}^{2+}$ color series are not present at Sites 722 and 728 , indicating that variation in the oxidation state of iron is not an important influence on sediment color at these sites. Because color variation in Oman margin and Owen Ridge sediments is primarily associated with one color sequence, determination of color change as variation of gray level on black-and-white photographs yields consistent patterns. Variation of optical density for sediments at Sites 722 and 728 shows distinct patterns of increasing (darkening) with increasing terrigenous sediment abundance (decreasing carbonate content) and increasing organic content (Fig. 6). These patterns are consistent with the previously described influences of factors affecting sediment color. Identifying the relative contributions of organic carbon concentration and terrigenous sediment abundance to color change is difficult. This problem is partly a limitation of using variation in gray level as a measure of color change and not identifying colors distinctive of organic matter or terrigenous sediments. It is also partly a consequence of organic carbon and carbonate concentration not varying strictly independently of each other. Figure 6 does show that optical density variation is more sensitive to small changes in organic carbon concentration than to changes in carbonate or terrigenous sediment abundance.

At both Sites 722 and 728 there is a weak correlation between wet-bulk density and sediment color, with bulk density decreasing as the darkness of the sediment (optical density) increases (Figs. 4 and 5). The influence of organic carbon concentration on variation of wet-bulk density and optical density is probably a significant factor contributing to a correlation between bulk density and sediment color. Lack of a stronger relationship be- 

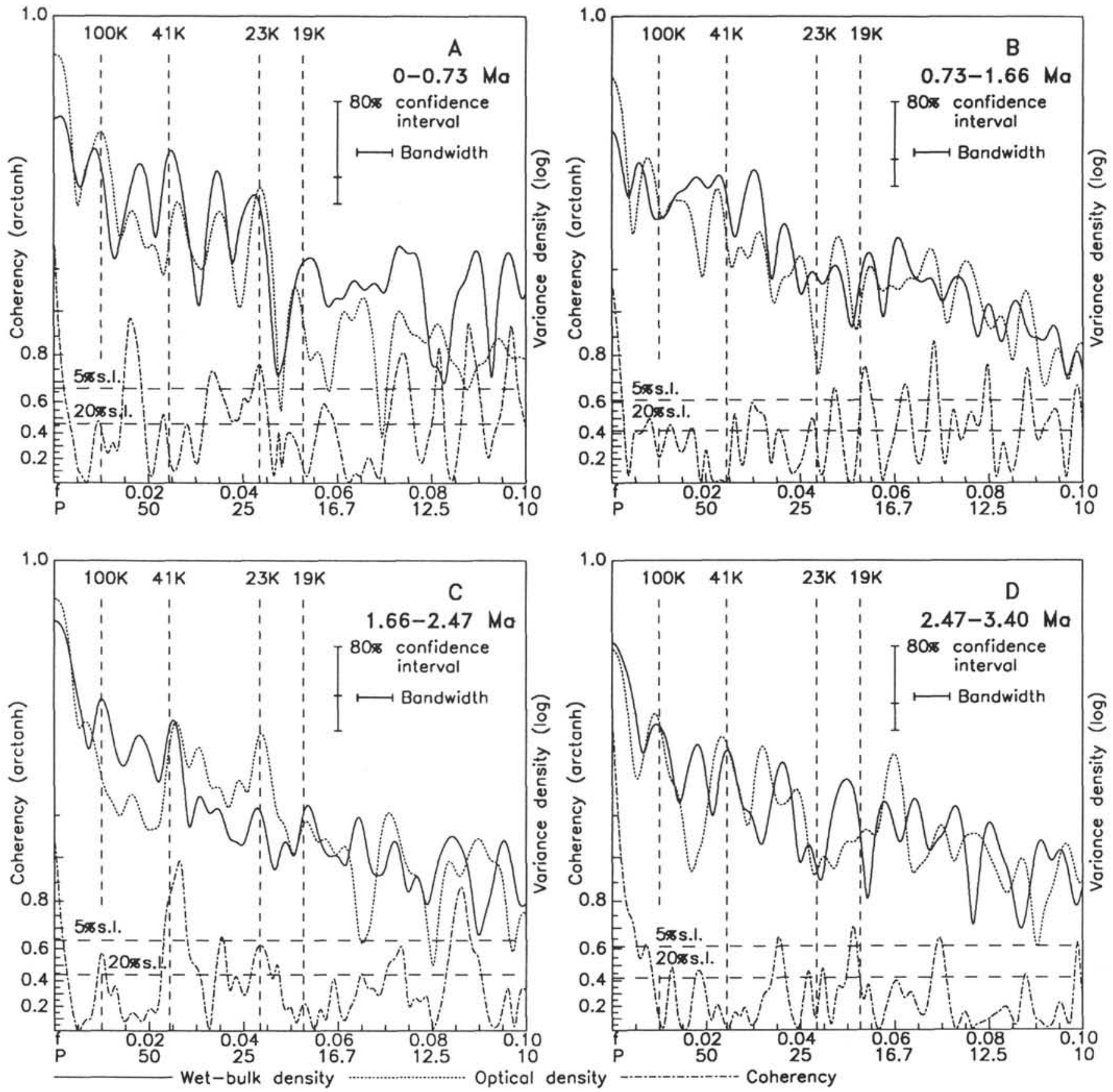

Figure 10. Normalized variance spectra for wet-bulk density (solid line) and optical density (dash line) and coherency spectrum between wet-bulk density and optical density (long-and-short-dash line) at Site 722 for the past 3.40 m.y., divided into four time slices. Variance spectra are plotted on arbitrary log scales with the bandwidth and $80 \%$ confidence interval indicated. The coherency spectrum is plotted on a hyperbolic arctangent scale with 5\% and 20\% significance levels indicated. A. 0-0.73 Ma. B. 0.73-1.66 Ma. C. 1.66-2.47 Ma. D. 2.47-3.40 Ma.

tween these two parameters is most likely the consequence of the apparent lack of a relationship between wet-bulk density and terrigenous sediment abundance.

\section{Cyclicity of Wet-Bulk Density and Sediment Color}

Identifying the cause of the cyclicity of wet-bulk density and sediment color is difficult because neither parameter varies as a consequence of variation of a single sediment component. Examination of the late Pleistocene wet-bulk density and optical density times series provides insight into the characteristics of the bulk density and color cycles and some of their complexities. At Site 722 there is a general pattern of dark colored sedi- ment coinciding with glacial periods (Figs. 7 and 9). Murray et al. (1988) and Clemens and Prell (this volume) have shown that glacial periods are characterized by higher terrigenous sediment accumulation rates, suggesting the correlation of dark sediment color with greater abundance of terrigenous constituents. This correlation is partially supported by the pattern of wet-bulk density variation which is characterized over the past 0.35 m.y. by the association of higher bulk density during glacial periods (Figs. 8 and 9). If increased abundance of organic matter were responsible for the darker sediment color, the sediments deposited during glacial periods should be characterized by lower wetbulk density. For upper Pleistocene sediments older than 0.35 

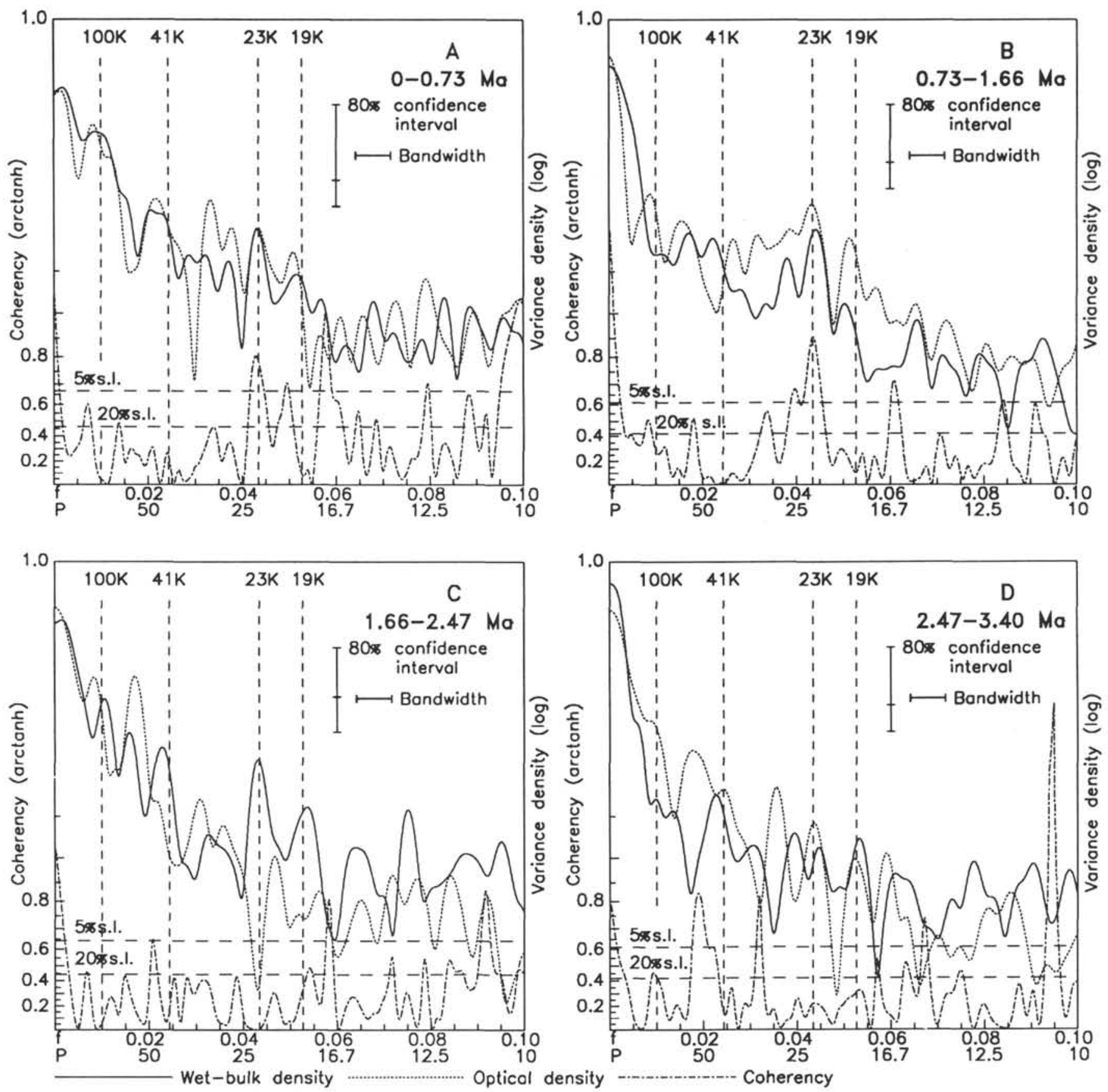

Figure 11. Normalized variance spectra for wet-bulk density (solid line) and optical density (dash line) and coherency spectrum between wet-bulk density and optical density (long-and-short-dash line) at Site 728 for the past $3.40 \mathrm{~m}$.y., divided into four time slices. Variance spectra are plotted on arbitrary log scales with the bandwidth and $80 \%$ confidence interval indicated. The coherency spectrum is plotted on a hyperbolic arctangent scale with $5 \%$ and $20 \%$ significance levels indicated. A. 0-0.73 Ma. B. $0.73-1.66$ Ma. C. $1.66-2.47$ Ma. D. $2.47-3.40$ Ma.

Ma at Site 722, sediments deposited during glacial periods are darker than interglacial sediments; however, there is not a consistent pattern of higher bulk density associated with the glacial sediments, suggesting a greater role of organic matter abundance in darkening sediment color. In the upper Pleistocene section at Site 728 there are intervals in which sediments deposited during glacial periods are darker than adjacent interglacial sediment; however, this pattern is not consistent for the entire upper Pleistocene section (Figs. 7 and 9). Sediments at Site 728 are characterized by higher and more variable organic carbon concentrations than those at Site 722 , and the variability in organic carbon abundance most likely accounts for the lack of a pattern similar to color variation at Site $\mathbf{7 2 2}$. At Site 728 wet-bulk density variation is characterized by higher density glacial sediments and lower density interglacial sediments for the past 0.35 m.y., with a lack of a consistent pattern for older upper Pleistocene sediments (Figs. 8 and 9). Only sediments deposited during oxygen isotope stages 6 and 8 display a clear association of dark colored sediment and higher wet-bulk density. Again, variability in the abundance of organic matter in these sediments may be responsible for the lack of a consistent pattern.

Comparison of wet-bulk density and optical density time series for upper Pleistocene sediments at Sites 722 and 728 suggests that periods when terrigenous sediments are a more im- 
Table 4. Summary of results of spectral and cross spectral analyses of wet-bulk density and optical density time series.

\begin{tabular}{|c|c|c|c|c|c|c|c|c|}
\hline \multirow{2}{*}{$\frac{\text { Site }}{722}$} & \multirow{2}{*}{$\begin{array}{l}\text { Interval } \\
0-0.73 \mathrm{Ma}\end{array}$} & \multicolumn{2}{|l|}{ Spectrum } & \multicolumn{4}{|c|}{ Spectral peak periodicities } & \multirow[b]{2}{*}{18.5} \\
\hline & & wet-bulk density & 117 & 55.1 & 40.4 & 30.0 & 23.6 & \\
\hline & & optical density & 101 & 60.7 & 38.4 & 28.6 & 22.9 & 19.5 \\
\hline & & coherency & 107 & 62.0 & & 29.7 & 23.0 & \\
\hline & $0.73-1.66 \mathrm{Ma}$ & wet-bulk density & 171 & 56.5 & 43.8 & $33.0,27.3$ & 21.0 & 18.3 \\
\hline & & optical density & 131 & 70.0 & 44.5 & $31.9,25.0$ & 20.7 & 18.2 \\
\hline & & coherency & 124 & $80.3,58.4$ & & 33.5 & 21.0 & 18.6 \\
\hline & $1.66-2.47 \mathrm{Ma}$ & wet-bulk density & 97.2 & 55.0 & 39.4 & $32.3,28.9$ & 23.2 & 18.6 \\
\hline & & optical density & 143 & 60.3 & 38.5 & 32.5 & 22.8 & 18.7 \\
\hline & & coherency & 100 & & 37.5 & 28.2 & 22.9 & \\
\hline & $2.47-3.4 \mathrm{Ma}$ & wet-bulk density & 101 & 53.4 & 40.1 & 27.3 & 23.8 & 20.0 \\
\hline & & optical density & 105 & & 42.0 & $30.9,25.4$ & & \\
\hline & & coherency & 130 & $74.8,52.6$ & & 27.8 & 23.8 & 19.3 \\
\hline \multirow[t]{11}{*}{728} & $0-0.73 \mathrm{Ma}$ & wet-bulk density & 104 & & 45.3 & $33.0,26.9$ & 23.0 & 19.3 \\
\hline & & optical density & 118 & & 45.6 & $30.1,26.4$ & 22.9 & 19.6 \\
\hline & & coherency & 138 & & & & 23.2 & 20.1 \\
\hline & $0.73-1.66 \mathrm{Ma}$ & wet-bulk density & & 58.2 & 44.7 & 26.4 & 22.5 & 19.8 \\
\hline & & optical density & 113 & 63.8 & 37.8 & 31.6 & 23.0 & 19.4 \\
\hline & & coherency & 119 & 55.0 & & $29.8,25.2$ & 22.8 & \\
\hline & $1.66-2.47 \mathrm{Ma}$ & wet-bulk density & 90.4 & 61.3 & 43.2 & 30.2 & 23.0 & 18.5 \\
\hline & & $\begin{array}{l}\text { optical density } \\
\text { coherency }\end{array}$ & 113 & 56.9 & & $31.9,27.6$ & 21.6 & \\
\hline & $2.47-3.40 \mathrm{Ma}$ & wet-bulk density & 100 & 72.1 & 43.1 & $32.2,25.2$ & 22.2 & 18.6 \\
\hline & & optical density & 106 & 55.0 & 40.2 & 27.9 & 22.8 & 19.0 \\
\hline & & coherency & 102 & 51.7 & & 30.9 & & \\
\hline
\end{tabular}

portant coloring agent can be distinguished from periods when organic matter abundance plays a greater role in darkening sediment color. This mixture of cycle types is consistent with the weak correlation between wet-bulk density and optical density at Sites 722 and 728 (Figs. 4 and 5) and may also be reflected in patterns displayed by the coherency spectra. A general characteristic of coherency spectra for the various time intervals at Sites 722 and 728 is coherence at periods of 23 k.y. and a lack of coherence at periods of 41 k.y. Phase spectra (not shown) indicate that coherence is greatest between wet-bulk density and optical density time series when they are strongly out of phase. This condition represents the situation where abundant organic matter causes dark sediment colors (high optical density) and low wet-bulk density. Significant coherence at the 23-k.y. periodicity suggests that increased abundance of organic matter, relative to that of terrigenous components, may be an important cause of the cyclicity of bulk density and sediment color at this periodicity. Lack of coherence between wet-bulk density and optical density at the $41-\mathrm{k} . \mathrm{y}$. periodicity suggests that sediment coloration at this periodicity is a combination of effects of organic matter and terrigenous sediment abundance.

The extent to which fluctuations in biogenic silica abundance affects wet-bulk density cyclicity is uncertain. Murray and Prell (this volume) have determined that during the past 400 k.y., variation in opal concentration in Owen Ridge sediments is in phase with other indices of monsoon strength which are characterized by a dominant $23-k$.y. periodicity. If this pattern typifies sediment accumulation for the past $3.4 \mathrm{~m} . \mathrm{y}$. on the Owen Ridge and Oman margin, it might contribute to amplifying the association of low wet-bulk density and dark sediment color that is characterized by significant coherence at the 23-k.y. periodicity. However, intervals where there is a distinct increase in biogenic silica abundance, such as the upper Pliocene section at Site 728 , are characterized by a breakdown in the relationship between sediment color and wet-bulk density (Fig. 5) and a lack of coherency between these parameters in the precession frequency band (Fig. 11).

Identifying the specific processes responsible for the wetbulk density and sediment color cycles is difficult because both parameters are affected by more than one variable, and both global and regional scale climatic processes affect sedimentation on the Owen Ridge and Oman margin. Distinction of global cli- matic processes (changes in global ice volume) and regional processes (variation in monsoon intensity) is difficult because the periodicities associated with these processes are not unique. Recognition of monsoonal influence on sedimentation has been accomplished by identifying specific indicators of variability of monsoon strength and monsoon-induced upwelling, such as key planktonic foraminifer species ( $G$. bulloides) (Prell, 1984a; 1984b) or grain size of terrigenous sediment components (Clemens and Prell, this volume). The abundance of $G$. bulloides and terrigenous-component grain size have been shown to vary coherently with the 23-k.y. precessional component of the earth's orbit, which is believed to be the solar radiation component forcing the monsoon. The influence of global-scale processes has been established by determination that variation in terrigenous sediment accumulation on the Owen Ridge is coherent with global ice volume (Murray et al., 1988; Clemens and Prell, in press), with periods of increased terrigenous accumulation coinciding with glacial periods. Increased terrigenous accumulation during these periods is consistent with results of climate model simulations (Prell and Kutzbach, 1987) which show that glacial intervals are characterized by decreased monsoon wind strength and increased continental aridity.

Concentration of variance at the 41-k.y. periodicity in wetbulk density and optical density spectra for Sites 722 and 728 (Figs. 10 and 11) is most likely an indication of the influence of global climatic processes on sedimentation on the Owen Ridge and Oman margin. The general lack of coherence between wetbulk density and optical density at the 41-k.y. period at Sites 722 and 728 most likely reflects greater terrigenous sediment abundance and the combination of terrigenous components and organic matter affecting changes in wet-bulk density and sediment color. Spectra of wet-bulk density and optical density at Sites 722 and 728 are generally characterized by concentration of variance at the 23-k.y. periodicity and significant coherence at this periodicity. Significant coherence at this periodicity may be the expression of greater influence of organic matter abundance on sediment color and wet-bulk density and possibly a response to fluctuations in monsoon strength. Increased organic carbon concentration is a plausible product of increased productivity and preservation accompanying increased intensity of coastal upwelling as a consequence of increased monsoon strength. However, the validity of the inference that varying 
abundance of organic matter reflects changes in monsoon strength is uncertain. Murray and Prell (this volume) have concluded that there is no strong association between organic carbon concentration in Owen Ridge sediments and regional or global environmental change. If opal concentration varies with a dominant 23-k.y. periodicity, as suggested by Murray and Prell (this volume), its variation may be reflected in the relationship between wet-bulk density and sediment color in the precession frequency band. Determination of the influence of fluctuations in biogenic silica abundance on the wet-bulk density cycles awaits further investigation.

\section{SUMMARY}

Upper Pliocene to Holocene nannofossil oozes and marly nannofossil oozes of the Owen Ridge at Site 722 and Oman margin at Site 728 are characterized by a strong cyclicity of sediment color and wet-bulk density. A weak correlation exists between wet-bulk density and sediment color at both sites. Wetbulk density variation is characterized by an inverse relationship with organic carbon concentration and an ambiguous relationship with the relative abundance of calcium carbonate and terrigenous components. Sediment color darkens with increasing abundance of terrigenous sediments and with increasing organic carbon concentration.

Late Pleistocene time series of optical density show that at Site 722 dark sediment intervals coincide with glacial periods, whereas at Site 728 the timing of occurrence of dark intervals is more varied. At both sites dark intervals in the upper Pleistocene sections do not display a regular pattern of being characterized by either higher or lower wet-bulk density than adjacent intervals. Variation in the relationship between sediment color and wet-bulk density in these sections suggests that the role of terrigenous sediments and organic matter as the primary component responsible for darkening sediment color varies.

Spectra of wet-bulk density and optical density time series for the 3.4-m.y. records at Sites 722 and 728 display a concentration of variance at all periodicities corresponding to those of the earth's orbital parameters, suggesting that the bulk density and color cycles are a response to climate forcing. A strong 41k.y. periodicity characterizes spectra for most of the time intervals examined and is typified by a lack of coherence between wet-bulk density and optical density. The $41-\mathrm{k}$.y. periodicity is inferred to be a mixed signal of the effects of varying abundance of terrigenous sediments and organic matter on wet-bulk density and sediment color. The demonstration that changes in terrigenous sediment accumulation rates are coherent with global changes in ice volume suggests that the 41-k.y. periodicity in wet-bulk density and sediment color is strongly influenced by global processes. The $23-k$.y. periodicity in wet-bulk density and optical density time series is generally accompanied by significant coherence between the two parameters and is inferred to represent a greater role of organic carbon concentration affecting changes in wet-bulk density and sediment color. The association of the 23-k.y. periodicity of wet-bulk density and sediment color cycles with changes in organic carbon content possibly indicates changes in productivity or preservation associated with variation in intensity of monsoonal upwelling.

\section{ACKNOWLEDGMENTS}

I wish to thank Cindy Bray, Roman Bilak, and the technical staff on board the JOIDES Resolution who helped collect the GRAPE data. Barbara Triplett generously provided access to the video densitometer and instruction on its operation, and Marian Bennett assisted in processing the GRAPE and optical density data. Thanks are also due to Steve Clemens and Dick
Kroon, who provided oxygen isotope age data. This research was completed with funds provided by the U.S. Science Program associated with the Ocean Drilling Program, sponsored by the National Science Foundation and the Joint Oceanographic Institutions, Inc. Conclusions expressed in this publication are those of the author and do not necessarily reflect the view of the National Science Foundation, the Joint Oceanographic Institutions, Inc., or the Texas A\&M University.

\section{REFERENCES}

Blatt, H., 1982. Sedimentary Petrology: San Francisco (W. H. Freeman).

Boyce, R. E., 1976. Definitions and laboratory techniques of compressional sound velocity parameters and wet-water content, wet-bulk density, and porosity parameters by gravimetric and gamma ray attenuation techniques. In Schlanger, S. O., Jackson, E. D., et al., Init. Repts. DSDP, 33: Washington (U.S. Govt. Printing Office), 931-958.

Bryant, W. R., Bennett, R., and Katherman, C., 1981. Shear strength, consolidation, porosity, and permeability of marine sediments. In Emiliani, C. (Ed.), The Sea (Vol. 7): New York (Wiley), 1555-1616.

Clemens, S. C., and Prell, W. L., in press. Late Pleistocene variability of Arabian Sea summer-monsoon winds: an eolian record from the lithogenic component of deep-sea sediments. Paleoceanography.

Cullen, J., and Prell, W. L., 1984. Planktonic foraminifera of the northern Indian Ocean: distribution and preservation in surface sediments. Mar. Micropaleontol., 9:1-52.

deMenocal, P. B., 1989. Episodes in the late Neogene development of the Asian monsoon. EOS, Trans. Am. Geophys. Union, 70:373.

Hamilton, E. L., 1974. Prediction of deep-sea sediment properties: state of the art. In Inderbitzen, A. L. (Ed.), Deep-Sea Sediments: Physical and Mechanical Properties: New York (Plenum), 1-43.

, 1976. Variations of density and porosity with depth in deepsea sediments. J. Sediment. Petrol., 46:280-300.

Hurd, D. S., and Theyer, F., 1977. Changes in the physical and chemical properties of biogenic silica from the central equatorial Pacific: Part II. Refraction index, density, and water content of acid cleaned samples. Am. J. Sci., 227:1168-1202.

Jenkins, G. M., and Watts, D. G., 1968. Spectral Analysis and Its Applications: Oakland (Holden Day).

Kolla, V., Be, A., and Biscaye, P. E., 1976. Calcium carbonate distribution in the surface sediments of the Indian Ocean. J. Geophys. Res., $81: 2605-2616$.

Murray, D. W., Clemens, S. C., and Prell, W. L., 1988. Pelagic sediment flux rates in the northern Arabian Sea: terrigenous dilution of biogenic sedimentation. EOS, Trans. Am. Geophys. Union, 69:377.

Potter, P. E., Maynard, J. B., and Pryor, W. A., 1980. Sedimentology of Shale: New York (Springer-Verlag).

Prell, W. L., 1984a. Variation of monsoonal upwelling: a response to changing solar radiation. In Hansen, J. E., and Takahashi, T. (Eds.), Climatic Processes and Climate Sensitivity. Am. Geophys. Union, Maurice Ewing Ser., 5:48-57.

1984b. Monsoonal climate of the Arabian Sea during the late Quaternary: a response to changing solar radiation. In Berger, A., and Imbrie, J. (Eds.), Milankovitch and Climate: Dordrecht (D. Reidel), 349-366.

Prell, W. L., and Kutzbach, J. E., 1987. Monsoon variability over the past 150,000 years. J. Geophys. Res., 92:8411-8425.

Prell, W. L., Niitsuma, N., et al., 1989. Proc. ODP, Init. Repts., 117: College Station, TX (Ocean Drilling Program).

Priestley, M. B., 1981. Spectral Analysis and Time Series: London (Academic Press).

Pusch, R., 1973. Influence of organic matter on the geotechnical properties of clays. Natl. Swedish Bldg. Res., 11.

Reimers, C. E., 1982. Organic matter in anoxic sediments off central Peru: relations of porosity, microbial decomposition and deformation properties. Mar. Geol., 46:175-197.

Robert, P., 1988. Organic Metamorphism and Geothermal History: Dordrecht (D. Reidel).

Date of initial receipt: 3 August 1989

Date of acceptance: 20 February 1990

Ms 117B-190 